\title{
Response of Some Agronomic, Physiological and Anatomical characters for Some Bread Wheat Genotypes Under Water Deficit in North Delta Region
}

\author{
Farhat, W. Z. E. ${ }^{1}$, Rania A. Khedr ${ }^{2}$, Shimaa A. Shaaban*3 \\ ${ }^{1}$ Wheat Research Department, Field Crops Research Institute, ARC, Egypt \\ ${ }^{2}$ Crops physiology Research Department, Field Crops Research Institute, ARC, Egypt \\ ${ }^{3}$ Department of Agricultural Botany, Faculty of Agriculture, Cairo University, Giza, Egypt. \\ *Corresponding author: Email: sh.agribotany@gmail.com
}

Received on: 27-9-2021

Accepted on: 15-11-2021

\begin{abstract}
Two field experiments were performed on Sakha Agricultural Research Station Farm during 2017/18 and 2018/19 growing seasons, to study the agronomic, physiological, and anatomical response of eleven bread wheat cultivar and lines for two irrigation regimes levels (i.e., five irrigations, (recommended as control) and only one irrigation after 21 days planting (water stress)). Results showed that the agronomic (i.e., number of days to maturity, plant height, grain yield and its components), physiological (i.e., relative water content, and chlorophyll a \& b) and anatomocal estimates (i.e., thickness of leaf lamina, cuticle layer, upper epidermis, lower epidermis, mesophyll tissue, midrib, main vascular bundle dimension (length and width), collenchyma tissue, xylem tissue, phloem tissue and bulliform cells) were decreased under water stress conditions, except for proline and leaf temperature. Line 1, Line 2, Sids 14, Giza 171 and Sakha 95 were the most tolerant genotypes and may be suitable for water shortage conditions. High values of relative water content, chlorophyll and proline contents, low values of flag leaf temperature, in addition to the lowest reduction in leaf anatomical characters may be useful selection criteria for water stress tolerance in bread wheat.
\end{abstract}

KEYWORDS: Wheat, water deficit, tolerance index, physiology and leaf anatomy

\section{INTRODUCTION}

Wheat (Triticum aestivum L. em. Thell.) is one of the most important and widely cultivated cereal crops in Egypt and worldwide. Water stress is the most environmental limiting factor facing crop productivity (Mujeeb-Kazi et al., 2019). In addition, global climate change is increasing the severity of water stress (Fang and Xiong 2015 and Senapati et al., 2019). The development of tolerant genotypes using present genetic resources is an important strategy to increase wheat production in the semiarid areas and means to cope with water stress (Mwadzingeni et al., 2016 and Wasaya et al., 2021).

Water stress has harmful effects and brings morphological, physiological, biochemical, anatomical and molecular changes in plants. Generally, decreasing agronomic and morphological characters were observed under the water stress condition (Shalaby et al., 2020, Shehab-Eldeen and Farhat, 2020, Morsy et al., 2021, Mu et al., 2021, Nehe et al., 2021 and Wasaya et al., 2021).

At the level of physiological response, there were decreasing effects on relative water and chlorophyll contents under water stress (Wasaya et al., 2021). In contrast, proline and leaf temperature was reported to be increased under the water stress conditions (El-Gammaal, 2018, Din et al., 2020 and Mu et al., 2021).

Different plant features such as leaf anatomy have been considered as an indicator of stress symptoms and useful for water stress tolerance (Niinemets and Sack 2006). Furthermore, the anatomical changes in the leaf may help plants to maintain high levels of photosynthetic rates and high transpiration efficiencies (Evans et al., 1994). Cuticle thickness (Rojas et al., 1983) is believed to be useful for breeding for water stress-tolerant genotypes.

Water stress tolerance as a trait can be assessed from correlated traits with high yield under these conditions or from drought indices which accurately assess the genotypic yield response to drought stress (Al-Naggar et al., 2020 Shehab-Eldeen and Farhat, 2020, El Gataa et al., 2021, Morsy et al., 2021, and Nehe et al., 2021).

Consequently, this research aimed to: (1) understand water deficit effects on the agronomic, physiological and anatomical levels, (2) identify tolerant genotypes of bread wheat to water deficit (3) assess reliable multiple selection indices for water deficit tolerance in bread wheat. 


\section{MATERIALS AND METHODS}

\subsection{Plant materials and experimental design}

This study was conducted on Sakha Agricultural Research Station Farm (Egypt; 38 $8^{\circ} 52^{\prime} \mathrm{N} 65^{\circ} 48^{\prime} \mathrm{E}, 6 \mathrm{~m}$ ) with clay soil. Eleven Egyptian bread wheat cultivars and lines (Table 1) were evaluated using the flood irrigation method under two irrigation treatments the $1^{\text {st }}$ one was normal (five irrigations including planting irrigation), while the $2^{\text {nd }}$ one was water deficit (only one irrigation 21 days after the planting irrigation). The experiment was performed on $30^{\text {th }}$ and $25^{\text {th }}$, November during 2017/18 and 2018/19 wheat growing seasons, respectively.
The genotypes were studied under each water treatment separately and the randomized complete blocks design with four replications was used. Each plot involved two rows $2.5 \mathrm{~m}$ long and $30 \mathrm{~cm}$ apart. Each experiment was enclosed by a $5 \mathrm{~m}$ border to reduce the lateral movement of irrigation water. Location of experiments was close to main drainage. Levels of the water table were measured at intervals through irrigation procedures. All cultural practices, except irrigation were applied as recommended by Wheat Research Department for Delta region of Egypt. The previous crop was maize in the two growing seasons. Data of Sakha meteorological station and Water amounts of irrigations across two seasons are presented in Tables 2 and 3.

Table 1. Names and pedigrees of the studied wheat genotypes.

\begin{tabular}{|c|c|c|}
\hline Name & Pedigree and selection history ${ }^{*}$ & Origin \\
\hline \multirow{2}{*}{ Giza 168} & MRL / BUC // SERI & EGYPT \\
\hline & CM93046-8M-0Y-0M-2Y-0B-0GZ & \\
\hline \multirow{2}{*}{ Giza 171} & SAKHA 93/GEMMEIZA 9 & EGYPT \\
\hline & S. 6-1GZ-4GZ-1GZ-2GZ-0S & \\
\hline \multirow{2}{*}{ Sakha 95} & PASTOR // SITE / MO /3/ CHEN / AEGILOPS SQUARROSA (TAUS) // BCN /4/ WBLL1. & EGYPT \\
\hline & CMA01Y00158S-040POY-040M-030ZTM-040SY-26M-0Y-0SY-0S. & \\
\hline \multirow{2}{*}{ Gemmeiza 12} & OTUS/3/SARA/THB//VEE & EGYPT \\
\hline & CMSS97Y00227S-5y-010M-010Y-010M-2Y-1M-0Y-OGM & \\
\hline \multirow{2}{*}{ Shandweel 1} & SITE/MO/4/NAC/TH. AC//3*PVN/3/MIRLO/BUC & EGYPT \\
\hline & CMSS93B00567S-72Y-010M-010Y-010M-3Y-0M-0HTY-0SH & \\
\hline \multirow{3}{*}{ Sids 12} & BUC//7C/ALD/5/MAYA74/ON//1160.147/3/BB/GLL/4/CHAT"S"/6/MAYA/VUL//CMH74 & EGYPT \\
\hline & A. $630 / 4 * S X$ & \\
\hline & SD7096-4SD-1SD-1SD-0SD & \\
\hline \multirow{2}{*}{ Sids 14} & Bow"s"/Vee"s"//Bow's'/Tsi/3/BANI SUEF 1 & EGYPT \\
\hline & SD293-1SD-2SD-4SD-0SD & \\
\hline \multirow{3}{*}{ Misr 3} & ATTILA*2/PBW65*2/KACHU & EGYPT \\
\hline & CMSS06Y00582T-099TOPM-099Y-099ZTM-099Y-099M-10WGY-0B-0EGY & \\
\hline & CHEN/AEGILOPS SQUARROSA(TAUS) // BCN /3/ 2* KAUZ /4/ GEN*2 // BUC / FLK & EGYPT \\
\hline \multirow[t]{2}{*}{ Line 1} & /3/ BUCHIN. & \\
\hline & S. 16280-020S-015S-4S-0S & \\
\hline \multirow[t]{2}{*}{ Line 2} & WBLL1*2/4/BABAX/LR42//BABA×/3/BABX/LR42//BABAX. & CIMMYT \\
\hline & CMSS06Y00885T-099TOPM-099Y-099ZTM-099NJ-099NJ-26WGY-0B-0EGY & CIIVIVY I \\
\hline \multirow[t]{2}{*}{ Line 3} & BAJ1/3/KIRITATI//ATTILA*2/PASTOR. & CIMMYT \\
\hline & CMSS07Y00288S-0B-099Y-099M-099Y-1M-0WGY-0EGY & CIMIVY I \\
\hline
\end{tabular}

* Source: Wheat Research Department

Table 2. Monthly mean air temperature $\left(\mathrm{At}{ }^{\mathrm{O}} \mathrm{C}\right)$, mean relative humidity (RH \%) and rainfed (mm/month) in winter seasons, 2017/18 and 2018/19 at Sakha site.

\begin{tabular}{lllllllll}
\hline Month & AT $^{\mathbf{0}} \mathbf{C}$ 2017/18 & \multicolumn{2}{l}{ AT $^{\mathbf{0}} \mathbf{C ~ 2 0 1 8 / 1 9}$} & \multicolumn{2}{l}{ RH \% } & \multicolumn{2}{l}{ Rainfall (mm) } \\
\cline { 2 - 9 } & Max. $^{*}$ & Min. & Max. & Min. & $\mathbf{2 0 1 7 / 1 8}$ & $\mathbf{2 0 1 8 / 1 9}$ & $\mathbf{2 0 1 7 / 1 8}$ & $\mathbf{2 0 1 8 / 1 9}$ \\
\hline November & 25.3 & 13.4 & 27.0 & 15.2 & 62.2 & 57.6 & 30.0 & 10.1 \\
December & 22.0 & 11.5 & 21.0 & 10.7 & 68.1 & 63.9 & 4.1 & 12.5 \\
January & 19.7 & 8.9 & 19.3 & 6.7 & 67.9 & 53.0 & 29.7 & 6.1 \\
February & 23.2 & 10.3 & 21.4 & 7.8 & 60.5 & 57.0 & 5.6 & 6.7 \\
March & 29.3 & 12.1 & 24.0 & 9.5 & 44.2 & 54.8 & 1.8 & 16.7 \\
April & 31.5 & 14.3 & 28.2 & 12.4 & 43.4 & 47.3 & 11.5 & 3.0 \\
May & 36.1 & 19.2 & 36.7 & 17.4 & 40.8 & 34.1 & 0.0 & 0.0 \\
\hline
\end{tabular}

$*$ Max = maximum and Min = minimum 
Farhat WZE et al., 2021

Table 3. Amount of supplied water in $\mathrm{m}^{3}$ fed ${ }^{-1}$. during wheat growing seasons 2017/18 and 2018/19.

\begin{tabular}{|c|c|c|c|c|}
\hline \multirow{2}{*}{ Supplied water } & \multicolumn{2}{|c|}{$2017 / 18$} & \multicolumn{2}{|c|}{ 2018/19 } \\
\hline & Normal & Deficit & Normal & Deficit \\
\hline Planting irrigation & \multicolumn{2}{|c|}{485.0} & \multicolumn{2}{|c|}{495.0} \\
\hline Second irrigation & \multicolumn{2}{|c|}{300.0} & \multicolumn{2}{|c|}{310.0} \\
\hline Remaining irrigations & - & 1010.0 & - & 1060.0 \\
\hline Total irrigation & 1795.0 & 785.0 & 1865.0 & 805.0 \\
\hline Rainfall & \multicolumn{2}{|c|}{347.3} & \multicolumn{2}{|c|}{231.2} \\
\hline Total of water & 2142.3 & 1132.3 & 2096.2 & 1036.2 \\
\hline
\end{tabular}

\subsection{Data recorded}

Agronomic data were recorded on No. of days to maturity, plant height $(\mathrm{cm})$, No. of spikes $\mathrm{m}^{-2}$, No. of kernels spike ${ }^{-1}, 1000$-kernel weight $(\mathrm{g})$ and grain yield $\left(\mathrm{kg} \mathrm{m}^{-2}\right)$. The physiological characteristics were estimated using randomly taken flag leaves samples from each plot at heading stage.

Relative water content (RWC \%) were determined by Gonzalez and Gonzalez (2001) as follows:

$$
\text { RWC\% }=\frac{\mathbf{F W}-\mathbf{D W}}{\mathbf{T W}-\mathbf{D W}} \mathbf{1 0 0}
$$

Where FW is the sample fresh weight, TW is the sample turgid weight, and DW is the sample dry weight

Proline content ( $\mathrm{mg} \mathrm{g}^{-1} \mathrm{FW}$,) was determined according to Bates et al. (1973) and Photosynthetic pigments of chlorophyll-a and $b\left(\mu \mathrm{g} \mathrm{ml}^{-1}\right)$ were determined using the spectrophotometric method according to the equation

chl a $=12.64 \mathrm{~A}_{664}-2.99_{\mathrm{A} 647}$

chl $\mathrm{b}=-5.6 \mathrm{~A}_{664}+23.26 \mathrm{~A}_{647}$ as described by Moran, 1982.

Leaf temperature was estimated by a portable steady-state promoter (LI- COR model LI- 1600) on a central portion of fully expanded flag leaves from two randomly selected plants in each plot during the midday period, and in the absence of cloud cover. Air temperature ranged from 18.0 to $22.0{ }^{\circ} \mathrm{C}$ at the time of measuring in the seasons.

Stress susceptibility index (SSI) was calculated according to Fischer and Maurer (1978).

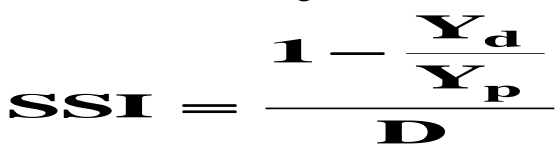

Where: $Y_{d}=$ mean yield under water stress, $Y_{p}=$ mean yield under normal, $\mathrm{D}=$ water stress intensity $=1$ (mean $\mathrm{Y}_{\mathrm{d}}$ of all genotypes / mean $\mathrm{Y}_{\mathrm{p}}$ of all genotypes).

Specimens of about $1 \mathrm{~cm}$ were taken from the central part of the flag leaf. Specimens were fixed in Formalin Alcohol Acetic acid mixture (FAA, 1:18:1 $\mathrm{v} / \mathrm{v})$, dehydrated in alcohol series. The dehydrated specimens were embedded in paraffin wax $\left(52-54{ }^{\circ} \mathrm{C}\right)$. The embedded specimens were sectioned on a rotary microtome at a thickness of $20 \mu \mathrm{m}$. Staining sections with crystal violet and erthrosine, cleared in xylol and mounted in Canada balsam (Willey, 1971). Five reading from each slide were examined with an electric microscope (Leica DM LS) with a digital camera (Leica DC300), then photographed and calculated. The studied anatomical characters were average thickness of leaf lamina, cuticle layer, upper epidermis, lower epidermis, mesophyll tissue, midrib, main vascular bundle dimension (length and width), collenchyma tissue, xylem tissue, phloem tissue and bulliform cells.

The analysis of variance was performed according to RCBD. Combined analysis across the two water treatments in the two seasons was performed when the assumption of errors homogeneity cannot be rejected (Levene, 1960). Means of genotypes were compared using LSD at 0.05 probability level according to Steel et al. (1997). Seasons were random, while the water treatments and genotypes were fixed. Spearman rank correlation was also calculated. The statistical analyses were performed using the statistical routines available in Microsoft EXCEL (2016) and GenStat 18 (Payne et al., 2017).

\section{RESULTS}

\subsection{Analysis of variance:}

Tables 4 and 5 show the analysis of variance for the studied characters across seasons and water treatments. Mean squares due to seasons, water treatments and genotypes were significant or highly significant $(P \leq 0.05$ or $P \leq 0.01)$ for all the studied characters, except water treatments for 1000-kernel weight. These results indicated that the two seasons and two irrigation treatments behaved differently and detected sufficient genetic variability among the studied genotypes.

Variances of seasons, water treatments and 
Scientific Journal of Agricultural Sciences 3 (2): 145-160, 2021

Table 4. Analysis of variance for the plant height, grain yield and its components across the seasons, water treatments and studied wheat genotypes.

\begin{tabular}{llllllll}
\hline SOV & df & DM & PH & SM & KS & KW & GY \\
\hline Seasons (S) & 1 & $27134.6^{* *}$ & $14911.4^{* *}$ & $159401.6^{* *}$ & $1098^{* *}$ & $2857.4^{* *}$ & $2.49^{* *}$ \\
Water treatment (W) & 1 & $1685.6^{* *}$ & $2705.1^{* *}$ & $192236.4^{* *}$ & $174.4^{* *}$ & 46.4 & $1.88^{* *}$ \\
S x W & 1 & $266.7^{* *}$ & $300.6^{* *}$ & $35606.1^{* *}$ & 24.7 & 0.7 & $0.38^{* *}$ \\
Reps/W/S = Error (a) & 12 & 8.7 & 21.5 & 3091.7 & 18.6 & 15.2 & 0.01 \\
Entry (E) & 10 & $54.4^{* *}$ & $601.9^{* *}$ & $84462.1^{* *}$ & $43.2^{* *}$ & $211^{* *}$ & $0.5^{* *}$ \\
S x E & 10 & $23.1^{* *}$ & $82.6^{* *}$ & 5769.8 & 21.2 & $65.8^{* *}$ & $0.08^{* *}$ \\
W x E & 10 & 0.653 & 20.114 & 5097.677 & 1.155 & 1.321 & $0.02^{* *}$ \\
S x W x E & 10 & 2.6 & $23.7^{*}$ & 2077.1 & 2.0 & 0.5 & $0.01^{*}$ \\
Pooled error b & 120 & 1.4 & 11 & 3238 & 16.8 & 4 & 0.005 \\
Total & 175 & & & & & & \\
CV ( E) & & 0.86 & 3.35 & 11.65 & 7.07 & 4.28 & 7.71 \\
\hline$*, * *=$ &
\end{tabular}

, ** = significant at 0.05 and 0.01 , probability levels, respectively. $\mathrm{DM}=$ No. of days to maturity, $\mathrm{PH}=$ plant height, $\mathrm{SM}=$ No. of spikes $\mathrm{m}^{-2}, \mathrm{KS}=$ No. of kernels spike ${ }^{-1}, \mathrm{KW}=1000$-kernel weight $(\mathrm{g})$ and $\mathrm{GY}=$ grain yield.

Table 5. Analysis of variance for the physiological characters across the seasons, water treatments and studied wheat genotypes.

\begin{tabular}{lllllll}
\hline SOV & df & RWC & pro & chl a & chl b & LT \\
\hline Seasons (S) & 1 & $611.2^{* *}$ & $0.2^{* *}$ & $1347.5^{* *}$ & $57.8^{* *}$ & $16.6^{*}$ \\
Water treatment (W) & 1 & $7614.4^{* *}$ & $1.3^{* *}$ & $280.5^{* *}$ & $43.9^{* *}$ & $185.1^{* *}$ \\
S x W & 1 & 11.5 & 0.001 & 4.1 & 0.01 & 6.6 \\
Reps/W/S = Error (a) & 12 & 16.2 & 0.01 & 4.7 & 0.5 & 2.2 \\
Entry (E) & 10 & $111.6^{* *}$ & $0.02^{* *}$ & $24.7^{* *}$ & $0.9^{* *}$ & $5.5^{* *}$ \\
S x E & 10 & $11.1^{* *}$ & $0.01^{* *}$ & $12.8^{* *}$ & $0.6^{* *}$ & $0.7^{* *}$ \\
W x E & 10 & $15.749^{* *}$ & $0.01^{* *}$ & $2.768^{* *}$ & $0.624^{* *}$ & $1.383^{* *}$ \\
S x W x E & 10 & $8.8^{* *}$ & 0.001 & $1.9^{* *}$ & $0.2^{* *}$ & $0.8^{* *}$ \\
Pooled error b & 120 & 2.7 & 0.001 & 0.3 & 0.04 & 0.2 \\
Total & 175 & & & & & \\
CV ( E) & & 2.17 & 10.75 & 4.03 & 5.28 & 2.28 \\
\hline
\end{tabular}

$*, * *=$ significant at 0.05 and 0.01 , probability levels, respectively. $\mathrm{RWC}=$ relative water content percent, pro $=$ proline ( $\left.\mathrm{mg} \mathrm{g}^{-1} \mathrm{FW}\right), \mathrm{chl} \mathrm{a}=$ chlorophyll-a, chl $\mathrm{b}=$ chlorophyll-b and LT $=$ leaf temperature.

genotypes interaction were significant for all characters, except the interaction of seasons $\mathrm{x}$ water treatments for No. of kernels spike ${ }^{-1}, 1000$-kernel weight, relative water content, proline content, chlorophyll-a and $\mathrm{b}$ and leaf temperature; season $\mathrm{x}$ genotypes for No. of spikes $\mathrm{m}^{-2}$ and No. of kernels spike $^{-1}$; water treatments $\mathrm{x}$ genotypes for No. of days to maturity, plant height, No. of spikes $\mathrm{m}^{-2}$, No. of kernels spike $^{-1}$, and 1000-kernel weight; and season $\mathrm{x}$ water treatments $\mathrm{x}$ genotypes for No. of days to maturity, No. of spikes $\mathrm{m}^{-2}$, No. of kernels spike ${ }^{-1}$, 1000-kernel weight and proline content.

\subsection{Mean performance}

Averaging across the two seasons and water treatments are shown in Table 6. Number of days to maturity varied from 135.3 days in Line 1 to 140.5 days in Shandaweel 1. In addition, plant height estimates were in the range of $87.5 \mathrm{~cm}$ in Sids 12 and $107.5 \mathrm{~cm}$ in Sids 14. Besides, the highest and lowest
No. of spikes $\mathrm{m}^{-2}$ (589.8 and 364.2 spikes) were detected by Line 2 and Sids 12, respectively. Moreover, No. of kernels spike ${ }^{-1}$ ranged from 60.6 kernels (Misr 3) to 55.6 kernels (Giza 168). Also, the range of 1000-kernel weight varied from $52.1 \mathrm{~g}$ in Giza 171 to $40.8 \mathrm{~g}$ in Giza 168. Moreover, the highest grain yield was observed by Sakha $95(1.193 \mathrm{~kg})$ and Misr 3 (1.151 kg), while the lowest value was obtained by Sids $12(0.593 \mathrm{~kg})$.

For the physiological characters, RWC \% varied from $72.1 \%$ in Giza 168 to $79.9 \%$ in Sids14. Moreover, free proline content in flag leaves were in the range of $0.258 \mathrm{mg} \mathrm{g}^{-1}$ fresh weight in Giza 168 and Line 3 and $0.362 \mathrm{mg} \mathrm{g}^{-1} \mathrm{~F} \mathrm{~W}$ in Sids14. In addition, the concentrations of chlorophyll-a extended from $10.32 \mu \mathrm{g} \mathrm{ml}^{-1}$ in Giza 168 to $14.53 \mathrm{mg} \mathrm{L}^{-1}$ in Sids 14 , while chlorophyll-b fluctuated from $3.36 \mathrm{mg} \mathrm{L}^{-1}$ in Line3 to $4.05 \mu \mathrm{g} \mathrm{ml}^{-1}$ in Giza 168 and Sakha 95. Moreover, mean values of leaf temperature ranged from $19.66^{\circ} \mathrm{C}$ in Sids 14 to $21.88^{\circ} \mathrm{C}$ in Line 2. 
Farhat WZE et al., 2021

Table 6. Mean performance of studied genotypes for the studied characters combined over seasons and water treatments.

\begin{tabular}{|c|c|c|c|c|c|c|c|c|c|c|c|}
\hline Genotype & DM & PH & SM & KS & KW & GY & RWC & pro & chl a & chl b & LT \\
\hline Giza 168 & 140.1 & 91.9 & 532.1 & 55.6 & 40.8 & 0.958 & 72.1 & 0.258 & 10.32 & 4.05 & 20.57 \\
\hline Giza 171 & 140.1 & 101.9 & 428.5 & 59.0 & 52.1 & 1.009 & 78.0 & 0.305 & 13.54 & 3.56 & 20.98 \\
\hline Sakha 95 & 136.3 & 105.9 & 580.4 & 58.0 & 50.1 & 1.193 & 77.5 & 0.313 & 14.43 & 4.05 & 20.38 \\
\hline Gemmeiza 12 & 137.6 & 97.5 & 452.5 & 59.0 & 42.3 & 0.848 & 73.4 & 0.307 & 13.22 & 3.57 & 21.05 \\
\hline Shandaweel 1 & 140.5 & 95.6 & 499.0 & 56.6 & 42.0 & 0.828 & 75.6 & 0.307 & 13.38 & 3.77 & 20.93 \\
\hline Sids 12 & 136.7 & 87.5 & 364.2 & 60.1 & 46.3 & 0.593 & 76.1 & 0.298 & 13.63 & 3.50 & 21.25 \\
\hline Sids 14 & 139.3 & 107.5 & 479.2 & 58.5 & 47.2 & 1.054 & 79.9 & 0.362 & 14.53 & 3.79 & 19.66 \\
\hline Misr 3 & 140.1 & 94.4 & 396.7 & 60.6 & 47.7 & 1.151 & 78.8 & 0.348 & 14.47 & 3.87 & 20.29 \\
\hline Line 1 & 135.3 & 102.2 & 510.0 & 57.7 & 45.9 & 1.067 & 75.2 & 0.307 & 13.46 & 3.65 & 20.64 \\
\hline Line 2 & 138.4 & 98.4 & 589.8 & 56.4 & 48.0 & 1.127 & 73.5 & 0.279 & 12.16 & 3.45 & 21.88 \\
\hline Line 3 & 139.9 & 103.4 & 540.8 & 56.1 & 50.0 & 1.107 & 72.4 & 0.258 & 12.31 & 3.36 & 21.19 \\
\hline Minimum & 135.3 & 87.5 & 364.2 & 55.6 & 40.8 & 0.593 & 72.1 & 0.258 & 10.32 & 3.36 & 19.66 \\
\hline Maximum & 140.5 & 107.5 & 589.8 & 60.6 & 52.1 & 1.193 & 79.9 & 0.362 & 14.53 & 4.05 & 21.88 \\
\hline Mean & 138.6 & 98.8 & 488.5 & 58.0 & 46.6 & 0.994 & 75.7 & 0.304 & 13.22 & 3.69 & 20.80 \\
\hline $\mathbf{L S D}_{0.05}$ & 0.8 & 2.3 & 39.8 & 2.9 & 1.4 & 0.049 & 1.2 & 0.023 & 0.37 & 0.14 & 0.33 \\
\hline
\end{tabular}

$\mathrm{DM}=$ No. of days to maturity, $\mathrm{PH}=$ plant height $(\mathrm{cm}), \mathrm{SM}=$ No. of spikes $\mathrm{m}^{-2}, \mathrm{KS}=$ No. of kernels spike ${ }^{-1}, \mathrm{KW}=1000-$ kernel weight $(\mathrm{g}), \mathrm{GY}=$ grain yield $\left(\mathrm{kg} \mathrm{m}^{-2}\right), \mathrm{RWC}=$ relative water content percent $)$, pro $=$ proline $\left(\mathrm{mg} \mathrm{g}^{-1} \mathrm{FW}\right), \mathrm{chl} \mathrm{a}=$ chlorophyll-a $\left(\mu \mathrm{g} \mathrm{ml}^{-1}\right)$, chl $\mathrm{b}=$ chlorophyll-b $\left(\mu \mathrm{g} \mathrm{ml}^{-1}\right)$ and $\mathrm{LT}=$ leaf temperature $\left({ }^{\mathrm{O}} \mathrm{C}\right)$.

\subsection{The effect of season and genotypes interaction}

Tables 7 and 8 show means of all studied characters across the water treatments and seasons. Values of No. of days to maturity ranged from 122.3 and 148.3 days in Line 1 to 130.6 days in Misr 3 and 153.4 days in Shandaweel 1 in the first and second seasons, respectively. Plant height estimates varied from 78.1 and $96.9 \mathrm{~cm}$ in Sids 12 to 98.8 and 116.3 $\mathrm{cm}$ in Sids 14 in the first and second season, respectively. Besides, No. of spikes $\mathrm{m}^{-2}$ were in the range of 327.1 and 401.3 spikes in Sids 12 and 551.7 in Sakha 95 and 648.8 spikes in Line 2 in the first and second seasons, correspondingly. Values of No. of kernels spike ${ }^{-1}$ varied from 52.5 in Shandaweel 1 and 57.2 kernels in Line 3 in the first season and 58.2 in Gemmeiza 12 and 64.1 kernels in Sids 12 in the second season. In addition, the lowest 1000-kernel weight was $35.0 \mathrm{~g}$ in Giza 168 and $42.2 \mathrm{~g}$ in Gemmeiza 12 and the highest values were 46.3 and $57.8 \mathrm{~g}$ in Giza 171 in the first and second season, respectively. The highest grain yields were $1.064 \mathrm{~kg}$ $\mathrm{m}^{-2}$ for Misr 3 and $1.334 \mathrm{~kg} \mathrm{~m}^{-2}$ for Sakha 95, while the lowest values were 0.470 and $0.715 \mathrm{~kg} \mathrm{~m}^{-2}$ for Sids 12 in the first season and second season, respectively.

Table 7: Mean performance of interaction between seasons and genotypes for days to maturity, plant height, grain yield and its components characters combined over water treatments.

\begin{tabular}{|c|c|c|c|c|c|c|c|c|c|c|c|c|}
\hline \multirow{2}{*}{ Genotype } & \multicolumn{2}{|c|}{ DM } & \multicolumn{2}{|c|}{ PH } & \multicolumn{2}{|c|}{ SM } & \multicolumn{2}{|c|}{ KS } & \multicolumn{2}{|c|}{ KW } & \multicolumn{2}{|c|}{ GY } \\
\hline & 17/18 & $18 / 19$ & $17 / 18$ & $18 / 19$ & 17/18 & $18 / 19$ & 17/18 & $18 / 19$ & $17 / 18$ & $18 / 19$ & $17 / 18$ & $18 / 19$ \\
\hline Giza 168 & 128.3 & 152.0 & 82.5 & 101.3 & 514.6 & 549.6 & 53.9 & 57.4 & 35.0 & 46.7 & 0.694 & 1.221 \\
\hline Giza 171 & 128.4 & 151.9 & 92.5 & 111.3 & 437.5 & 419.6 & 55.3 & 62.8 & 46.3 & 57.8 & 0.778 & 1.240 \\
\hline Sakha 95 & 123.6 & 148.9 & 96.9 & 115.0 & 551.7 & 609.2 & 55.4 & 60.6 & 44.3 & 56.0 & 1.053 & 1.334 \\
\hline Gemmeiza 12 & 124.9 & 150.4 & 87.5 & 107.5 & 430.4 & 474.6 & 58.2 & 59.8 & 42.4 & 42.2 & 0.809 & 0.887 \\
\hline Shandaweel 1 & 127.6 & 153.4 & 82.5 & 108.8 & 476.7 & 521.3 & 52.5 & 60.8 & 38.8 & 45.1 & 0.734 & 0.921 \\
\hline Sids 12 & 122.5 & 150.9 & 78.1 & 96.9 & 327.1 & 401.3 & 56.0 & 64.1 & 44.3 & 48.3 & 0.470 & 0.715 \\
\hline Sids 14 & 127.0 & 151.6 & 98.8 & 116.3 & 426.3 & 532.1 & 56.6 & 60.5 & 45.0 & 49.4 & 0.999 & 1.108 \\
\hline Misr 3 & 130.6 & 149.6 & 83.8 & 105.0 & 378.3 & 415.0 & 57.9 & 63.3 & 41.4 & 54.1 & 1.064 & 1.238 \\
\hline Line 1 & 122.3 & 148.3 & 96.9 & 107.5 & 471.7 & 548.3 & 54.8 & 60.6 & 41.7 & 50.0 & 0.958 & 1.175 \\
\hline Line 2 & 124.9 & 152.0 & 93.1 & 103.8 & 530.8 & 648.8 & 54.7 & 58.2 & 43.2 & 52.8 & 1.034 & 1.219 \\
\hline Line 3 & 127.8 & 152.1 & 92.5 & 114.4 & 497.1 & 584.6 & 55.0 & 57.2 & 45.7 & 54.3 & 1.032 & 1.183 \\
\hline $\mathbf{L S D}_{0.05}$ & \multicolumn{2}{|c|}{1.2} & \multicolumn{2}{|c|}{3.3} & \multicolumn{2}{|c|}{ NS } & \multicolumn{2}{|c|}{ NS } & \multicolumn{2}{|c|}{2.1} & \multicolumn{2}{|c|}{0.070} \\
\hline
\end{tabular}

$\mathrm{DM}=$ No. of days to maturity, $\mathrm{PH}=$ plant height $(\mathrm{cm}), \mathrm{SM}=$ No. of spikes $\mathrm{m}^{-2}, \mathrm{KS}=$ No. of kernels spike ${ }^{-1}, \mathrm{KW}=1000-$ kernel weight $(\mathrm{g}), \mathrm{GY}=$ grain yield $\left(\mathrm{kg} \mathrm{m}^{-2}\right)$ and $\mathrm{NS}=$ not significant. 
Scientific Journal of Agricultural Sciences 3 (2): 145-160, 2021

Table 8. Mean performance of interaction between seasons and genotypes for physiological characters combined over water treatments

\begin{tabular}{|c|c|c|c|c|c|c|c|c|c|c|}
\hline \multirow[t]{2}{*}{ Genotype } & \multicolumn{2}{|c|}{ RWC \% } & \multicolumn{2}{|c|}{ Pro } & \multicolumn{2}{|c|}{ chl a } & \multicolumn{2}{|c|}{ chl b } & \multicolumn{2}{|c|}{$\mathrm{LT}^{\circ} \mathrm{C}$} \\
\hline & $\overline{17 / 18}$ & $18 / 19$ & $17 / 18$ & $18 / 19$ & $17 / 18$ & $18 / 19$ & $17 / 18$ & $18 / 19$ & $17 / 18$ & $18 / 19$ \\
\hline Giza 168 & 71.49 & 72.66 & 0.263 & 0.252 & 10.11 & 10.53 & 4.19 & 3.91 & 20.82 & 20.32 \\
\hline Giza 171 & 75.30 & 80.66 & 0.362 & 0.248 & 10.76 & 16.31 & 4.44 & 2.68 & 21.27 & 20.68 \\
\hline Sakha 95 & 75.37 & 79.60 & 0.347 & 0.280 & 11.47 & 17.39 & 4.59 & 3.51 & 20.60 & 20.17 \\
\hline Gemmeiza 12 & 72.10 & 74.77 & 0.347 & 0.267 & 10.37 & 16.06 & 4.31 & 2.84 & 21.45 & 20.65 \\
\hline Shandaweel 1 & 72.45 & 78.81 & 0.365 & 0.248 & 10.20 & 16.56 & 4.45 & 3.09 & 21.68 & 20.18 \\
\hline Sids 12 & 73.46 & 78.64 & 0.307 & 0.290 & 10.29 & 16.98 & 4.05 & 2.95 & 21.85 & 20.65 \\
\hline Sids 14 & 77.81 & 81.98 & 0.415 & 0.309 & 11.39 & 17.67 & 4.35 & 3.24 & 19.84 & 19.48 \\
\hline Misr 3 & 77.22 & 80.38 & 0.387 & 0.308 & 11.46 & 17.48 & 4.44 & 3.30 & 20.63 & 19.95 \\
\hline Line 1 & 73.79 & 76.69 & 0.358 & 0.255 & 9.87 & 17.04 & 4.32 & 2.99 & 20.70 & 20.58 \\
\hline Line 2 & 71.25 & 75.82 & 0.313 & 0.245 & 9.38 & 14.94 & 3.92 & 2.99 & 22.08 & 21.68 \\
\hline Line 3 & 71.78 & 73.02 & 0.288 & 0.228 & 9.72 & 14.91 & 3.88 & 2.84 & 21.28 & 21.10 \\
\hline $\mathbf{L S D}_{0.05}$ & \multicolumn{2}{|c|}{1.63} & \multicolumn{2}{|c|}{0.032} & \multicolumn{2}{|c|}{0.53} & \multicolumn{2}{|c|}{0.19} & \multicolumn{2}{|c|}{0.47} \\
\hline
\end{tabular}

$\mathrm{RWC}=$ relative water content percent), pro $=$ proline $\left(\mathrm{mg} \mathrm{g}^{-1} \mathrm{FW}\right), \mathrm{chl} \mathrm{a}=$ chlorophyll-a $\left(\mu \mathrm{g} \mathrm{ml}^{-1}\right)$, chl $\mathrm{b}=$ chlorophyll-b $(\mu \mathrm{g}$ $\left.\mathrm{ml}^{-1}\right)$ and $\mathrm{LT}=$ leaf temperature $\left({ }^{\mathrm{O}} \mathrm{C}\right)$

For the physiological characters, the relative water $(\mathrm{RWC} \%)$ content had values from $71.25 \%$ in line 2 and $72.66 \%$ in Giza 168 to 77.81 and $81.98 \%$ in Sids 14 in the first and second seasons, respectively. The Proline contents were ranged from $0.263 \mathrm{mg} \mathrm{g}^{-1}$ FW in Giza 168 and $0.228 \mathrm{mg} \mathrm{g}^{-1} \mathrm{FW}$ in Line 3 to 0.415 and $0.309 \mathrm{mg} \mathrm{g}^{-1} \mathrm{FW}$ in Sids 14 in the first and second season, correspondingly.

Additionally, the concentrations of chlorophylla continued from $9.38 \mu \mathrm{g} \mathrm{ml}^{-1}$ in line 2 and $10.53 \mu \mathrm{g}$ $\mathrm{ml}^{-1}$ in Giza 168 to $11.47 \mu \mathrm{g} \mathrm{ml}^{-1}$ in Sakha 95 and $17.67 \mu \mathrm{g} \mathrm{ml}^{-1}$ in Sids 14 , while chlorophyll-b continued from 3.88 in Line 3 and $2.68 \mu \mathrm{g} \mathrm{ml}^{-1}$ in Giza 171 to 4.59 in Sakha 95 and $3.91 \mu \mathrm{g} \mathrm{ml}^{-1}$ in Giza 168 in the first and second season, respectively. The leaf temperature ranged from 19.84 and $19.48^{\circ} \mathrm{C}$ in Sids 14 to 22.08 and $21.68^{\circ} \mathrm{C}$ in Line 2 in the first and second season, respectively.

\subsection{The effect of water treatments and genotypes interaction}

The means of all studied characters combined over the two seasons for the same water treatment are exhibited in Tables 9 and 10. Number of days to maturity ranged from138.6 and 132 days in Line 1 to 143.6 and 137.4 days in Shandaweel1 under normal and water stress conditions, respectively. Plant height estimates varied from 90.6 and $84.4 \mathrm{~cm}$ in Sids 12 to 111.9 and $103.1 \mathrm{~cm}$ in Sakha 95 and Sids 14 under normal and water stress conditions, respectively. Besides, the number of spikes $\mathrm{m}^{-2}$ went in the range from 406.3 and 322.1 spikes in Sids 12 to 652.5 spikes in Sakha 95 and 565.4 spikes in Line 2 under normal and water stress conditions, respectively.

The number of kernel spike ${ }^{-1}$ varied between 56.5 kernels in Giza 168 and 54.4 kernels in Line 3to 61.5 and 59.6 kernels in Misr 3 under normal and water deficit conditions, respectively. The lowest kernel weights were 41.3 and $40.4 \mathrm{~g}$ in Giza 168, while the highest values were 52.6and $51.5 \mathrm{~g}$ in Giza 171 under normal and water stress conditions, respectively.

The lowest values of grain yield were 0.721 and $0.464 \mathrm{~kg} \mathrm{~m}^{-2}$ for Sids 12 , while the highest values were 1.287 and $1.099 \mathrm{~kg} \mathrm{~m}^{-2}$ for Sakha95 under normal and water stress conditions, respectively.

RWC \% had values from $77.94 \%$ in Line 3 and $64.65 \%$ in Giza 168 to 85.43 and $74.36 \%$ in Sids 14 under normal and water stress conditions, respectively.

Moreover, the proline contents ranged from $0.195 \mathrm{mg} \mathrm{g}^{-1} \mathrm{FW}$ in Line 3 and $0.287 \mathrm{mg} \mathrm{g}^{-1}$ fresh weight in Giza 168 to $0.245 \mathrm{mg} \mathrm{g}^{-1} \mathrm{FW}$ in Misr 3 and $0.485 \mathrm{mg} \mathrm{g}^{-1} \mathrm{FW}$ in Sids 14 under normal and water stress conditions, respectively.

The contents of chlorophyll-a extended from 11.70 and $8.94 \mu \mathrm{g} \mathrm{ml}^{-1}$ in Giza 168 to $15.53 \mu \mathrm{g} \mathrm{ml}^{-1}$ in Sakha 95 and $13.77 \mathrm{mg} \mathrm{L}^{-1}$ in Sids 14 and Misr 3, while chlorophyll-b extended from $3.66 \mu \mathrm{g} \mathrm{ml}^{-1}$ in Line 3 and $2.83 \mu \mathrm{g} \mathrm{ml}^{-1}$ in Line 1 to $4.80 \mu \mathrm{g} \mathrm{ml}^{-1}$ in Giza 168 and $3.53 \mu \mathrm{g} \mathrm{ml}^{-1}$ in Misr 3 under normal and water stress conditions, respectively.

Furthermore, the lowest leaf temperature was 18.60 and $20.73{ }^{\circ} \mathrm{C}$ in Sids 14 , while the highest values were 20.88 and $22.88{ }^{\circ} \mathrm{C}$ in Line 2 under normal and water stress conditions, respectively. 
Farhat WZE et al., 2021

Table 9. Mean performance of interaction between water treatments and genotypes for days to maturity, plant height, grain yield and its components characters combined over seasons

\begin{tabular}{|c|c|c|c|c|c|c|c|c|c|c|c|c|}
\hline \multirow{2}{*}{ Genotype } & \multicolumn{2}{|c|}{ DM } & \multicolumn{2}{|c|}{ PH } & \multicolumn{2}{|c|}{ SM } & \multicolumn{2}{|c|}{ KS } & \multicolumn{2}{|c|}{ KW } & \multicolumn{2}{|c|}{ GY } \\
\hline & \multicolumn{2}{|c|}{ Normal Stress } & \multicolumn{2}{|c|}{ Normal Stress } & \multicolumn{2}{|c|}{ Normal Stress } & \multicolumn{2}{|c|}{ Normal Stress } & \multicolumn{2}{|c|}{ Normal Stress } & \multicolumn{2}{|c|}{ Normal Stress } \\
\hline Giza 168 & 143.3 & 137.0 & 96.3 & 87.5 & 570.8 & 493.3 & 56.5 & 54.8 & 41.3 & 40.4 & 1.053 & 0.863 \\
\hline Giza 171 & 143.4 & 136.9 & 106.9 & 96.9 & 462.9 & 394.2 & 60.0 & 58.1 & 52.6 & 51.5 & 1.083 & 0.935 \\
\hline Sakha 95 & 139.1 & 133.4 & 111.9 & 100.0 & 652.5 & 508.3 & 59.2 & 56.8 & 50.9 & 49.4 & 1.287 & 1.099 \\
\hline Gemmeiza 12 & 140.6 & 134.6 & 101.3 & 93.8 & 499.6 & 405.4 & 59.8 & 58.2 & 42.7 & 41.8 & 1.016 & 0.679 \\
\hline Shandaweel 1 & 143.6 & 137.4 & 100.6 & 90.6 & 503.8 & 494.2 & 57.6 & 55.7 & 42.9 & 41.0 & 0.963 & 0.692 \\
\hline Sids 12 & 139.4 & 134.0 & 90.6 & 84.4 & 406.3 & 322.1 & 60.8 & 59.4 & 46.5 & 46.1 & 0.721 & 0.464 \\
\hline Sids 14 & 142.8 & 135.9 & 111.9 & 103.1 & 512.5 & 445.8 & 59.6 & 57.5 & 47.3 & 47.1 & 1.113 & 0.994 \\
\hline Misr 3 & 143.3 & 137.0 & 97.5 & 91.3 & 425.0 & 368.3 & 61.5 & 59.6 & 47.8 & 47.6 & 1.269 & 1.033 \\
\hline Line 1 & 138.6 & 132.0 & 105.0 & 99.4 & 523.3 & 496.7 & 58.5 & 56.9 & 46.6 & 45.1 & 1.143 & 0.991 \\
\hline Line 2 & 141.5 & 135.4 & 100.6 & 96.3 & 614.2 & 565.4 & 57.4 & 55.4 & 48.5 & 47.4 & 1.210 & 1.044 \\
\hline Line 3 & 143.0 & 136.9 & 106.9 & 100.0 & 565.8 & 515.8 & 57.8 & 54.4 & 50.7 & 49.4 & 1.212 & 1.003 \\
\hline $\mathbf{L S D}_{0.05}$ & \multicolumn{2}{|c|}{ NS } & \multicolumn{2}{|c|}{ NS } & \multicolumn{2}{|c|}{ NS } & \multicolumn{2}{|c|}{ NS } & \multicolumn{2}{|c|}{ NS } & \multicolumn{2}{|c|}{0.070} \\
\hline
\end{tabular}

$\mathrm{DM}=$ No. of days to maturity, $\mathrm{PH}=$ plant height $(\mathrm{cm}), \mathrm{SM}=$ No. of spikes $\mathrm{m}^{-2}, \mathrm{KS}=$ No. of kernels spike ${ }^{-1}, \mathrm{KW}=1000-$ kernel weight $(\mathrm{g}), \mathrm{GY}=$ grain yield $\left(\mathrm{kg} \mathrm{m}^{-2}\right)$ and $\mathrm{NS}=$ not significant .

Table 10. Mean performance of interaction between water treatments and genotypes for physiological characters combined over seasons.

\begin{tabular}{|c|c|c|c|c|c|c|c|c|c|c|}
\hline \multirow{2}{*}{ Genotype } & \multicolumn{2}{|c|}{ RWC } & \multicolumn{2}{|c|}{ Pro } & \multicolumn{2}{|c|}{ chl a } & \multicolumn{2}{|c|}{ chl b } & \multicolumn{2}{|c|}{ LT } \\
\hline & Normal & Stress & Normal & Stress & Norma & Stress & Normal & Stress & Normal & Stress \\
\hline Giza 168 & 79.50 & 64.65 & 0.228 & 0.287 & 11.70 & 8.94 & 4.80 & 3.31 & 19.33 & 21.80 \\
\hline Giza 171 & 84.20 & 71.76 & 0.220 & 0.390 & 14.45 & 12.62 & 4.01 & 3.11 & 19.78 & 22.17 \\
\hline Sakha 95 & 84.82 & 70.16 & 0.210 & 0.417 & 15.53 & 13.33 & 4.75 & 3.35 & 18.93 & 21.83 \\
\hline Gemmeiza 12 & 81.82 & 65.05 & 0.228 & 0.385 & 14.59 & 11.84 & 3.97 & 3.18 & 19.78 & 22.32 \\
\hline Shandaweel 1 & 81.86 & 69.40 & 0.215 & 0.398 & 14.92 & 11.84 & 4.42 & 3.12 & 20.10 & 21.77 \\
\hline Sids 12 & 83.82 & 68.28 & 0.202 & 0.395 & 14.62 & 12.65 & 3.79 & 3.21 & 20.38 & 22.12 \\
\hline Sids 14 & 85.43 & 74.36 & 0.239 & 0.485 & 15.29 & 13.77 & 4.29 & 3.30 & 18.60 & 20.73 \\
\hline Misr 3 & 84.29 & 73.31 & 0.245 & 0.450 & 15.16 & 13.77 & 4.21 & 3.53 & 19.43 & 21.15 \\
\hline Line 1 & 81.40 & 69.08 & 0.203 & 0.410 & 14.79 & 12.12 & 4.48 & 2.83 & 19.48 & 21.80 \\
\hline Line 2 & 79.80 & 67.27 & 0.203 & 0.355 & 14.00 & 10.32 & 3.75 & 3.15 & 20.88 & 22.88 \\
\hline Line 3 & 77.94 & 66.87 & 0.195 & 0.322 & 14.27 & 10.35 & 3.66 & 3.06 & 20.83 & 21.55 \\
\hline $\mathbf{L S D}_{0.05}$ & \multicolumn{2}{|c|}{1.63} & \multicolumn{2}{|c|}{0.032} & \multicolumn{2}{|c|}{0.53} & \multicolumn{2}{|c|}{0.19} & \multicolumn{2}{|c|}{0.47} \\
\hline
\end{tabular}

$\mathrm{RWC}=$ relative water content percent), pro $=$ proline $\left(\mathrm{mg} \mathrm{g}^{-1} \mathrm{FW}\right), \mathrm{chl} \mathrm{a}=$ chlorophyll-a $\left(\mu \mathrm{g} \mathrm{ml}^{-1}\right), \mathrm{chl} \mathrm{b}=$ chlorophyll-b $(\mu \mathrm{g}$ $\left.\mathrm{ml}^{-1}\right)$ and $\mathrm{LT}=$ leaf temperature $\left({ }^{\mathrm{O}} \mathrm{C}\right)$.

\subsection{The effect of season, water treatments and genotypes interaction}

The mean performance of the studied characters for the interaction seasons, water treatments and genotypes are demonstrated in Tables 11 and 12. The lowest number of days to maturity was belonged to Sids 12 and Sakha 95 under normal irrigation and to Line 1 under water stress in the two seasons, while the highest numbers were belonged to Misr 3 in the first season and to Shandaweel 1 in the second season. For plant height, Sids 12 and Giza 168 were the shortest genotypes, while Sids14, Sakha 95 and Line 3 were the tallest genotypes under most conditions. Besides, Sids 12 showed the least number of spikes $\mathrm{m}^{-2}$ under all conditions, however, Sakha95 revealed the highest number under normal conditions and Line 2 under water stress. Moreover, the lowest number of kernels spike $^{-1}$ was detected by Shandaweel 1 and Giza 168 and Line 3, while the highest number was given by Misr 3 and Gemmeiza 12 in the first season and Sids 12 in the second season, respectively. Additionally, the lowest weight of kernels was shown by Giza 168 in the first season and Gemmeiza 12 in the second season, while the highest weight was obtained by Giza 171 under all conditions. At the same time, Sids 12 had the least grain yield under all conditions, whereas Sakha 95 and Misr 3under all conditions and Giza 171 under water stress in the second season were the best ones. 
Table 11. The mean performance of days to maturity, plant height and grain yield and its components characters as affected by interactions among seasons, water treatments and genotypes.

\begin{tabular}{|c|c|c|c|c|c|c|c|c|c|c|c|c|c|c|c|c|c|c|c|c|c|c|c|c|}
\hline \multirow{3}{*}{ Genotype } & \multicolumn{4}{|c|}{ DM } & \multicolumn{4}{|c|}{ PH } & \multicolumn{4}{|c|}{ SM } & \multicolumn{4}{|c|}{ KS } & \multicolumn{3}{|c|}{ KW } & \multicolumn{5}{|c|}{ GY } \\
\hline & \multicolumn{2}{|c|}{$2017 / 2018$} & \multicolumn{2}{|c|}{$2018 / 2019$} & \multicolumn{2}{|c|}{$2017 / 2018$} & \multicolumn{2}{|c|}{ 2018/2019 } & \multicolumn{2}{|c|}{$2017 / 2018$} & \multicolumn{2}{|c|}{$2018 / 2019$} & \multicolumn{4}{|c|}{$2017 / 20182018 / 2019$} & \multicolumn{2}{|c|}{$2017 / 2018$} & \multicolumn{2}{|c|}{$2018 / 2019$} & \multicolumn{2}{|c|}{$92017 / 2018$} & \multicolumn{2}{|c|}{$2018 / 2019$} \\
\hline & $\mathbf{N}$ & $\mathbf{S}$ & $\mathbf{N}$ & $\mathbf{S}$ & $\mathbf{N}$ & $\mathbf{S}$ & $\mathbf{N}$ & $\mathbf{S}$ & $\mathbf{N}$ & $\mathbf{S}$ & $\mathbf{N}$ & $\mathbf{S}$ & $\mathbf{N}$ & $\mathbf{S}$ & $\mathbf{N}$ & $\mathbf{S}$ & $\mathbf{N}$ & $\mathbf{S}$ & $\mathbf{N}$ & $\mathbf{S}$ & $\mathbf{N}$ & $\mathbf{S}$ & & $\mathbf{S}$ \\
\hline Giza 168 & 132. & 3124.3 & 154.3 & 3149.8 & 85.0 & 80.0 & 107.5 & 595.0 & 544.2 & 2485. & 0597. & 5501.7 & 754.8 & 53.1 & 58.2 & 56.5 & 35.4 & 34.7 & 47.2 & 46.2 & 0.739 & 90.650 & 1.368 & 1.075 \\
\hline iza 171 & 133 & 123.8 & 3153.8 & 8150.0 & 97.5 & 87.5 & 116.3 & 3106.3 & 343. & 3431. & 482. & 5356.1 & 756.4 & 54.2 & 63.5 & 62.0 & 46.8 & 45.8 & 58.5 & 57.2 & 0.820 & 00.13 & 1.34 & 1.134 \\
\hline Sakha 95 & 128. & 5118.8 & 149.8 & 8148.0 & 101.3 & 392.5 & 122.5 & 5107.5 & 598. & $3505 .($ & 0706. & 7511.7 & 757.3 & 53.5 & 61.0 & 60.2 & 44.9 & 43.7 & 57.0 & 55.0 & 1.129 & $990.9 / 6$ & 1.445 & 1.223 \\
\hline Gemmeiza 12 & 129 & 3120.5 & 152.0 & 0148.8 & 88.8 & 86.3 & 113.8 & 8101.3 & 3444.2 & 2416.7 & 7555. & 0394.2 & 259.4 & 57.1 & 60.3 & 59.3 & 42.8 & 42.0 & 42.7 & 41.7 & 0.883 & 30.735 & 1.150 & 0.624 \\
\hline Shandaweel 1 & 132 & 0123.3 & 3155.3 & 3151.5 & 86.3 & 78.8 & 115.0 & 0102.5 & 480. & 0473.3 & 3527. & 5515.0 & 053.9 & 51.1 & 61.3 & 60.3 & 39.7 & 38.0 & 46.2 & 44.0 & 0.799 & 190.669 & 1.128 & 0.715 \\
\hline Sids 12 & 125. & 8119.3 & 3 153. & 0148.8 & 82.5 & 73.8 & 98.8 & 95.0 & 362. & 5291.7 & 7450. & 0352.5 & 556.9 & 55.1 & 64.6 & 63.7 & 44.8 & 43.8 & 48.3 & 48.3 & 0.518 & 80.42 & 0.925 & 0.505 \\
\hline & & 8122 & 15 & 814 & 100.0 & 97.5 & 123.8 & 810 & 34 & 041 & 558 & 04 & 258.2 & 55.0 & 60.9 & 60.1 & 45.2 & 44.9 & 49.5 & 49.3 & & 00.94 & 1. & 51.040 \\
\hline Misr 3 & 134. & 5126. & 815 & 014 & 86.3 & 81.3 & 108.8 & 81 & 39 & 736 & 45 & & 759.7 & 56.2 & 63.4 & 63.1 & 41.4 & 41.3 & 54.3 & 54.0 & 1.125 & 51.003 & 1.4 & +1.063 \\
\hline e 1 & 126 & 711 & & & 98.8 & 95.0 & 111.3 & & & & & & 055.3 & 54.3 & 61.8 & 59.5 & 42.0 & 41.4 & 51.3 & 48.8 & 1.000 & 0.9 & & 51. \\
\hline & 12 & 5120 & 315 & 515 & 93.8 & 92.5 & 107.5 & 510 & 54 & 051 & 768 & 36 & 256.1 & 53.2 & 58.8 & 57.6 & 43.8 & 42.7 & 53.3 & 52.2 & & 20.9 & & \\
\hline in & 132. & 3123.3 & 3153.8 & 8150 & 93.8 & 91.3 & 120.0 & 0108.8 & 525. & 0469.2 & 2606. & $756 ?$ & 557.5 & 52.5 & 58.2 & 56.3 & 46.5 & 44.9 & 54.9 & 53.8 & 1.100 & 00.96 & & 1.043 \\
\hline LSD0.05 & & NS & IS & & & 4.7 & & & & $\mathrm{~N}$ & S & & & NS & & & & NS & & & & 0.09 & & \\
\hline
\end{tabular}

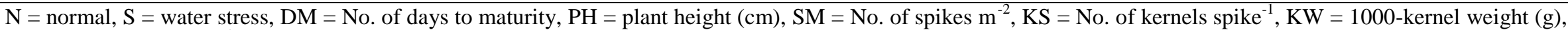
$\mathrm{GY}=$ grain yield $\left(\mathrm{kg} \mathrm{m}^{-2}\right)$ and $\mathrm{NS}=$ not significant.

Table 12. The mean performance of the physiological characters as affected by interactions among seasons, sowing dates and genotypes.

\begin{tabular}{|c|c|c|c|c|c|c|c|c|c|c|c|c|c|c|c|c|c|c|c|c|}
\hline \multirow{3}{*}{ Genotype } & \multicolumn{4}{|c|}{ RWC } & \multicolumn{4}{|c|}{ Pro } & \multicolumn{4}{|c|}{ chl a } & \multicolumn{4}{|c|}{ chl b } & \multicolumn{4}{|c|}{ LT } \\
\hline & \multicolumn{2}{|c|}{$2017 / 2018$} & \multicolumn{2}{|c|}{ 2018/2019 } & \multicolumn{2}{|c|}{$2017 / 2018$} & \multicolumn{2}{|c|}{ 2018/2019 } & \multicolumn{2}{|c|}{$2017 / 2018$} & \multicolumn{2}{|c|}{ 2018/2019 } & \multicolumn{2}{|c|}{$2017 / 2018$} & \multicolumn{2}{|c|}{ 2018/2019 } & \multicolumn{2}{|c|}{$2017 / 2018$} & \multicolumn{2}{|c|}{ 2018/2019 } \\
\hline & $\mathbf{N}$ & $\mathbf{S}$ & $\mathbf{N}$ & $\mathbf{S}$ & $\mathbf{N}$ & $\mathbf{S}$ & $\mathbf{N}$ & $\mathbf{S}$ & $\mathbf{N}$ & $\mathbf{S}$ & $\mathbf{N}$ & $\mathbf{S}$ & $\mathbf{N}$ & $\mathbf{S}$ & $\mathbf{N}$ & $\mathbf{S}$ & $\mathbf{N}$ & $\mathbf{S}$ & $\mathbf{N}$ & $\mathbf{S}$ \\
\hline Giza 168 & 79.00 & 63.98 & 80.00 & 65.32 & 0.233 & 0.293 & 0.223 & 0.280 & 11.37 & 8.85 & 12.03 & 9.02 & 4.97 & 3.42 & 2.63 & 3.19 & 19.67 & 21.97 & 19.00 & 21.63 \\
\hline Giza 171 & 82.15 & 68.44 & 86.24 & 75.07 & 0.283 & 0.440 & 0.157 & 0.340 & 11.72 & 9.80 & 17.18 & 15.44 & 4.99 & 3.89 & 3.03 & 2.33 & 20.20 & 22.33 & 19.37 & 22.00 \\
\hline kha 95 & 3.30 & 67.44 & 86.34 & 72.87 & 0.247 & 0.447 & 0.173 & $0.3 \xi$ & 12.52 & 10.42 & 54 & & 5.15 & & 4.34 & 67 & & .00 & 18.67 & 21.67 \\
\hline & 79.84 & 64.37 & 83.80 & 65.73 & 0.273 & 0 & 0.183 & & 11 & & 17 & & 4.69 & 92 & & & & .37 & 19.03 & 22.27 \\
\hline Shan & 77.54 & 67.37 & 86.19 & 71.43 & 0.257 & 0.473 & 0.173 & 0.323 & 11.96 & 8.4 & 17.88 & 15.24 & 4.93 & 98 & 3.91 & 2.2 & 53 & 1.83 & 18.67 & 21.70 \\
\hline Sids 12 & 81.29 & 65.63 & 86.35 & 70.93 & 0.217 & 0.397 & 0.187 & 0.393 & 11.34 & 9.2 & 17.89 & 16.06 & 4.36 & 3.74 & 3.22 & 2.67 & 21.47 & 22.23 & 19.30 & 22.00 \\
\hline ds 14 & 4.46 & 71.15 & 86.39 & 77.57 & 0.280 & 0.550 & 0.197 & 0.420 & 12.27 & 10.50 & 18.31 & 17.04 & 5.00 & 3.71 & 3.58 & 2.89 & 18.80 & 20.89 & 18.40 & 20.57 \\
\hline Misr 3 & 83.82 & 70.62 & 84.76 & 76.00 & 0.290 & 0.483 & 0.200 & 0.417 & 12.12 & 10.79 & 18.21 & 16.75 & 4.65 & 4.23 & 3.77 & 2.83 & 20.03 & 21.23 & 18.83 & 21.07 \\
\hline Line 1 & 80.86 & 66.72 & 81.94 & 71.43 & 0.247 & 0.470 & 0.160 & 0.350 & 11.19 & 8.55 & 18.39 & 15.70 & 5.20 & 3.44 & 3.75 & 2.22 & 19.53 & 21.87 & 19.43 & 21.73 \\
\hline Line 2 & 78.00 & 64.50 & 81.61 & 70.03 & 0.240 & 0.387 & 0.167 & 0.323 & 10.52 & 8.24 & 17.49 & 12.40 & 4.27 & 3.57 & 3.24 & 2.73 & 21.23 & 22.93 & 20.53 & 22.83 \\
\hline Line 3 & 76.93 & 66.64 & 78.95 & 67.10 & 0.237 & 0.340 & 0.153 & 0.303 & 10.80 & 8.63 & 17.74 & 12.08 & 4.15 & 3.62 & 3.18 & 2.51 & 20.87 & 21.70 & 20.80 & 21.40 \\
\hline LSD0.05 & & 0 & & & & 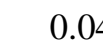 & & & & & & & & & & & & & & \\
\hline
\end{tabular}

$\mathrm{RWC}=$ relative water content percent $),$ pro $=$ proline $\left(\mathrm{mg} \mathrm{g}^{-1} \mathrm{FW}\right), \mathrm{chl} \mathrm{a}=$ chlorophyll-a $\left(\mu \mathrm{g} \mathrm{ml}^{-1}\right), \mathrm{chl} \mathrm{b}=$ chlorophyll-b $\left.\mu \mathrm{g} \mathrm{ml}{ }^{-1}\right)$ and $\mathrm{LT}=$ leaf temperature $\left({ }^{0} \mathrm{C}\right)$. 
For the physiological characters, Sids 14 showed the highest relative water content under all conditions, while Line 3 and Giza 168 showed the lowest content under normal and water stress, respectively. The highest contents were produced by Misr 3 and Giza 168 under normal irrigation and Sids 14 under water stress conditions, while the least contents belonged to Sids 12 and Line 3 under normal irrigation and Giza 168 under water stress condition. In addition, Line 2 gave the least chlorophyll-a estimates in the first season and Giza 168 in the second season, while the highest estimates belonged to Sakha 95 under normal conditions and Misr 3 and Sids 14 under water treatments in the two seasons. Also, the lowest chlorophyll-b values belonged to Line 3, Giza 168, Giza 171 and Line1 in the two seasons, while Line 1 and Misr 3 had the highest values in the first season and Giza 168 in the second season. Also, the lowest leaf temperature was given by Sids 14 in the two seasons and the highest temperature belonged to Shandaweel 1 and Line 3 under normal irrigation and Line 2 under water stress conditions in the two seasons.

\subsection{The effect of season, water treatments and their interaction}

Tables 13 show means of seasons, water treatments and their interaction across all studied genotypes. Means of studied genotypes for all traits were significantly higher in 2018/19 compared to 2017/18, except for proline contents, chlorophyll-b and leaf temperature (Tables 4 and 5).

Averaging across the 11 entries, the water stress conditions reduced all studied characters, except for proline content and leaf temperature.

Table 13. The mean performance of seasons, water treatments and their interaction for the studied characters.

\begin{tabular}{|c|c|c|c|c|c|c|c|c|c|c|c|c|}
\hline Season/treatment & & DM & PH & SM & KS & KW & GY & RWC & pro & chl a & chl b & LT \\
\hline $2017 / 18$ & & 126.2 & 88.9 & 458.4 & 55.5 & 41.9 & 0.875 & 73.8 & 0.34 & 10.5 & 4.27 & 21.1 \\
\hline 2018/19 & & 151.0 & 108.0 & 518.6 & 60.5 & 50.2 & 1.113 & 77.5 & 0.27 & 16.0 & 3.12 & 20.5 \\
\hline F test & & $* *$ & $* *$ & $* *$ & $* *$ & $* *$ & $* *$ & $* *$ & $* *$ & $* *$ & $*$ & $*$ \\
\hline Normal (N) & & 141.7 & 102.2 & 521.5 & 59.0 & 46.3 & 1.097 & 82.3 & 0.22 & 14.5 & 4.19 & 19.8 \\
\hline deficit $(S)$ & & 135.5 & 94.6 & 455.4 & 57.0 & 45.8 & 0.891 & 69.1 & 0.39 & 12.0 & 3.19 & 21.8 \\
\hline F test & & $* *$ & $* *$ & $* *$ & $* *$ & NS & $* *$ & $* *$ & $* *$ & $* *$ & $* *$ & $* *$ \\
\hline \multirow{2}{*}{$2017 / 18$} & $\mathbf{N}$ & 130.5 & 91.3 & 477.2 & 56.8 & 42.1 & 0.932 & 80.7 & 0.25 & 11.6 & 4.76 & 20.3 \\
\hline & $\mathbf{S}$ & 121.8 & 86.5 & 439.5 & 54.1 & 41.7 & 0.818 & 67.0 & 0.43 & 9.3 & 3.78 & 21.9 \\
\hline \multirow{2}{*}{ 2017/18 } & $\mathbf{N}$ & 152.9 & 113.2 & 565.8 & 61.1 & 50.5 & 1.262 & 83.9 & 0.18 & 17.4 & 3.63 & 19.3 \\
\hline & $\mathbf{S}$ & 149.1 & 102.7 & 471.3 & 59.8 & 49.9 & 0.963 & 71.2 & 0.35 & 14.6 & 2.61 & 21.7 \\
\hline $\mathbf{L S D}_{0.05}$ & & 1.37 & 2.2 & 25.8 & NS & NS & 0.041 & NS & NS & NS & NS & NS \\
\hline
\end{tabular}

$\mathrm{DM}=$ No. of days to maturity, $\mathrm{PH}=$ plant height $(\mathrm{cm}), \mathrm{SM}=$ No. of spikes $\mathrm{m}^{-2}, \mathrm{KS}=$ No. of kernels spike ${ }^{-1}, \mathrm{KW}=1000-$ kernel weight $(\mathrm{g}), \mathrm{GY}=$ grain yield $\left(\mathrm{kg} \mathrm{m}^{-2}\right), \mathrm{RWC}=$ relative water content percent $)$, pro = proline $\left(\mathrm{mg} \mathrm{g}^{-1} \mathrm{FW}\right), \mathrm{chl} \mathrm{a}=$ chlorophyll-a $\left(\mu \mathrm{g} \mathrm{ml}^{-1}\right)$, chl $\mathrm{b}=$ chlorophyll-b $\left.\mu \mathrm{g} \mathrm{ml}^{-1}\right)$ and $\mathrm{LT}=$ leaf temperature $\left({ }^{\mathrm{O}} \mathrm{C}\right)$ and $\mathrm{NS}=$ not significant.

\subsection{Water stress susceptibility index}

The water stress susceptibility index (SSI) was calculated using the grain yield $\mathrm{kg} \mathrm{m}^{-2}$ under normal and water deficit conditions (Table 14). The SSI values represent tolerance, moderate tolerance or sensitivity and sensitivity if they were less than, equal or near to and above unity, respectively. Averaging the mean of SSI values across the two seasons, Line 1, Line 2, Sids 14, Giza 171 and Sakha 95 had values less than the unity, Misr 3, Line 3 and Giza 168 had values around the unity and Shandaweel 1, Gemmeiza 12 and Sids 12 had values higher than the unity. These results indicate that the genotypes Line 1, Line 2, Sids 14, Giza 171 and Sakha 95were the most tolerant ones under water deficit. In addition, these genotypes showed preferable values of grain yield, relative water, proline, chlorophyll-a contents and cooler leaf temperatures.

\subsection{Reduction percentage and correlation}

Reduction \% due to water stress for the studied characters are shown in Table 15 . The means of reduction were in the positive direction for all studied characters except for porline content and leaf temperature. The least affected characters with the water stress were 1000-kernel weight and No. of kernels spike ${ }^{-1}(2.1$ and $2.0 \%)$ in the first and second season, respectively. On the contrary, the most affected characters were chlorophyll-b content (20.3 and $27.1 \%$ ), then chlorophyll-a and grain yield(19.3 and 24.7 in the first and second season, respectively.

Moreover, the increasing in average were 67.4 and $98.7 \%$ for proline, 8.3 and $12.8 \%$ for leaf 
Scientific Journal of Agricultural Sciences 3 (2): 145-160, 2021

Table 14. Estimates of stress susceptibility index (SSI) based on grain yield $\mathrm{kg} \mathrm{m}^{-2}$ for the studied genotypes in the two seasons.

\begin{tabular}{llll}
\hline Genotype & $\mathbf{2 0 1 7 / 1 8}$ & $\mathbf{2 0 1 8} / \mathbf{1 9}$ & Mean \\
\hline Giza 168 & 0.98 & 0.90 & 0.96 \\
Giza 171 & 0.84 & 0.66 & 0.73 \\
Sakha 95 & 1.10 & 0.65 & 0.77 \\
Gemmeiza 12 & 1.37 & 1.93 & 1.76 \\
Shandaweel 1 & 1.33 & 1.55 & 1.50 \\
Sids 12 & 1.50 & 1.92 & 1.89 \\
Sids 14 & 0.78 & 0.49 & 0.57 \\
Misr 3 & 0.88 & 1.05 & 0.99 \\
Line 1 & 0.68 & 0.72 & 0.71 \\
Line 2 & 0.87 & 0.69 & 0.73 \\
Line 3 & 1.01 & 0.90 & 0.91 \\
\hline
\end{tabular}

Table 15. Means and ranges of reduction \% due to water stress for the all studied characters during 2017/18 and 2018/19 seasons in addition to Spearman coefficient correlation among means of susceptibility index and the studied characters under normal and water deficit across the two seasons.

\begin{tabular}{|c|c|c|c|c|c|c|c|c|}
\hline \multirow{4}{*}{ Characters } & \multicolumn{6}{|c|}{ Reduction \% } & \multirow{3}{*}{\multicolumn{2}{|c|}{$\begin{array}{l}\text { Correlation coefficient } \\
\text { with water stress index }\end{array}$}} \\
\hline & \multirow{2}{*}{\multicolumn{2}{|c|}{ Mean }} & \multicolumn{4}{|c|}{$\begin{array}{l}\text { Range } \\
\end{array}$} & & \\
\hline & & & \multicolumn{2}{|c|}{ Minimum } & \multicolumn{2}{|c|}{ Maximum } & & \\
\hline & $2017 / 18$ & 2018/19 & $2017 / 18$ & $2018 / 19$ & $2017 / 18$ & $2018 / 19$ & Normal & Water stress \\
\hline No. of days to maturity & 6.6 & 2.4 & 5.2 & 1.2 & 7.6 & 3.1 & 0.15 & 0.23 \\
\hline Plant height & 5.7 & 9.1 & 1.3 & 3.8 & 10.6 & 12.2 & $-0.69 *$ & $-.78 * *$ \\
\hline No. of spikes $\mathrm{m}^{-2}$ & 7.9 & 16.8 & 1.4 & 2.4 & 19.5 & 29.0 & -0.48 & -0.45 \\
\hline No. of kernels spike ${ }^{-1}$ & 4.8 & 2.0 & 1.8 & 0.6 & 8.6 & 3.8 & 0.23 & 0.28 \\
\hline 1000-kernel weight & 2.1 & 2.3 & 0.1 & 0.1 & 4.3 & 5.0 & -0.52 & -0.48 \\
\hline Grain yield & 12.6 & 24.7 & 8.4 & 11.6 & 18.4 & 45.8 & -0.50 & -0.58 \\
\hline Relative water content & 16.9 & 15.1 & 13.1 & 10.2 & 19.4 & 21.6 & -0.14 & -0.41 \\
\hline Proline content & -67.4 & -98.7 & -96.4 & -123.1 & -25.7 & -25.4 & -0.03 & -0.26 \\
\hline Chlorophyll-a content & 19.3 & 16.6 & 10.9 & 6.9 & 29.5 & 31.9 & -0.10 & -0.10 \\
\hline Chlorophyll-b content & 20.3 & 27.1 & 9.1 & 15.6 & 33.8 & 42.0 & -0.19 & 0.26 \\
\hline Leaf temperature & -8.3 & -12.8 & -14.6 & -17.0 & -1.4 & -2.9 & 0.32 & 0.16 \\
\hline
\end{tabular}

$*$ and ** = Significant and highly significant at 0.01 probability level, respectively

temperature, respectively. The range of the reduction $\%$ ranged from -96.4 for proline content in the first season to $11.6 \%$ for grain yield in the second season. Table 12 shows Spearman correlation coefficients (r) among the mean of water stress susceptibility index and the studied characters under normal and water stress conditions. Significant (P-value $<0.01$ or 0.05 ) and negative correlation coefficient was detected among water stress susceptibility index and plant height under normal and water stress conditions. Water stress susceptibility index showed moderate insignificant and negative correlations with grain yield, No spike $\mathrm{m}^{-2}$ and 1000-kernel weight under all conditions and relative water content under water stress. The correlation coefficient was insignificant and positive between water susceptibility index and leaf temperature under normal conditions. The correlation coefficient for water stress susceptibility index was insignificant and positive with No. of kernels spike ${ }^{-1}$ under normal and water stress conditions.

\subsection{Leaf anatomy}

Three cultivars (Sakha 95 as tolerant and highyielding cultivars, Misr 3 as moderate tolerant cultivar and Shandaweel 1 as susceptible cultivar) were selected to perform the anatomical studies. The studied histological features and reduction percentage in transverse sections through flag leaf blade of Sakha 95, Misr 3 and Shandaweel 1 cultivars under normal and water stress conditions are shown in Table (16) and Figure (1). The histological features are the thickness of leaf lamina, cuticle layer, upper epidermis, lower epidermis, mesophyll tissue, midrib, 
Farhat WZE et al., 2021

Table 16. Measurements in micron $(\mu)$ of certain histological features and the reduction percentage $(\mathrm{D} \%)$ in cross-sections of flag leaf in Sakha 95, Misr 3 and Shandaweel 1wheat cultivars under normal $(\mathrm{N})$ and water stress $(\mathrm{S})$ conditions.

\begin{tabular}{llllllllll}
\hline \multirow{2}{*}{ Characters Av } & \multicolumn{3}{c}{ Sakha 95 } & \multicolumn{3}{c}{ Misr 3 } & \multicolumn{4}{c}{ Shandaweel 1 } \\
\cline { 2 - 10 } & $\mathbf{N}(\mathbf{1 0 0 \% )}$ & $\mathbf{S}$ & $\mathbf{D} \%$ & $\mathbf{N ~ ( 1 0 0 \% )}$ & $\mathbf{S}$ & D \% & $\mathbf{N}(\mathbf{1 0 0 \% )}$ & S & D \% \\
\hline Thickness of leaf lamina & 365.3 & 322.3 & 11.8 & 454.3 & 370.2 & 18.5 & 368.3 & 289.6 & 21.4 \\
Thickness of cuticle layer & 7.6 & 6.8 & 10.5 & 6.1 & 4.4 & 27.9 & 6.7 & 4.6 & 31.3 \\
Thickness of upper epidermis & 22.4 & 18.5 & 17.4 & 30.1 & 22.9 & 23.9 & 30.1 & 21.7 & 27.9 \\
Thickness of lower epidermis & 18.5 & 17.3 & 6.5 & 26.3 & 21.1 & 19.8 & 24.3 & 19 & 21.8 \\
Thickness of mesophyll tissue & 330.9 & 280.9 & 15.1 & 406.5 & 322.8 & 20.6 & 303.1 & 235.2 & 22.4 \\
Thickness of midrib & 852.7 & 745.5 & 12.6 & 858.4 & 740.1 & 13.8 & 891.4 & 760.2 & 14.7 \\
Main vascular bundle Length & 166.9 & 156.4 & 6.3 & 210.4 & 190.9 & 9.3 & 188.6 & 166.9 & 11.5 \\
Main vascular bundle Width & 213.2 & 185.9 & 12.8 & 226.2 & 194.3 & 14.1 & 219.7 & 185.9 & 15.4 \\
Thickness of collenchyma tissue & 344.6 & 293.3 & 14.9 & 566.8 & 464.4 & 18.1 & 435.6 & 347.8 & 20.2 \\
xylem tissue thickness & 52.6 & 45.3 & 13.9 & 61.3 & 52.4 & 14.5 & 58.9 & 49.9 & 15.3 \\
phloem tissue thickness & 49.7 & 47.4 & 4.6 & 55.9 & 49.8 & 10.9 & 62.3 & 49.6 & 20.4 \\
Thickness of the bulliform cells & 48.1 & 41.1 & 14.6 & 55.2 & 45.3 & 17.9 & 55.9 & 44.9 & 19.7 \\
\hline
\end{tabular}

main vascular bundle dimension (length and width), collenchyma tissue, xylem tissue, phloem tissue and bulliform cells. The obtained results showed that the means of the three cultivars for all leaf anatomical characters decreased under water stress. Relative to normal condition, the thinnest leaf lamina was found in Shandweel $1(289.6 \mu)$ while the thickest one was found in Misr $3(370.2 \mu)$. The reduction occurs in leaf lamina thickness accomplished by another reduction in mesophyll tissue. The maximum reduction percentage in mesophyll thickness was found in Shandaweel 1 (22.4\%) followed by Misr 3(20.6\%) and Sakha 95(15.1\%). Misr 3 obtained the highest values for most leaf anatomical characteristics, followed by Shandaweel 1, and then Sakha 95 under normal and water stress conditions. Moreover, the most susceptible cultivar Shandaweel 1 obtained the highest deficiency percentages (11.5-31.3\%) of all studied leaf anatomical characteristics due to water stress, followed by the moderate tolerant Misr 3 cultivar (9.3$27.9 \%$ ), and then the more tolerant Sakha 95 cultivar (4.6-17.4\%).

The anatomical characteristics of the more tolerant variety (Sakha 95) confirmed these results, as it was found that mesophyll cells were more compact compared to the other two genotypes. Moreover, the stomata in this genotype appear closed and sunken on both surfaces under water stress. In addition, this genotype showed an increased cuticle layer under the two conditions compared to the other two genotypes.

\section{DISCUSSION}

The studied genotypes were prevented from irrigation for about 130 days started from elongation stage in most genotypes until harvesting. Meantime, rainfall reached $347.3 \mathrm{~m}^{3} \mathrm{fed}^{-1}$ and $231.2 \mathrm{~m}^{3} \mathrm{fed}^{-1}$ in the first and second season, respectively. Moreover, the deepness of water table was more than $170 \mathrm{~cm}$ after 65 and 150 days from sowing under the water deficit and normal conditions, respectively in the two seasons. Consequently, water shortage allowed the comparisons of normal and water stress treatments.

Based on the analysis of variance, the two seasons and two irrigation treatments behaved differently and the studied genotypes had sufficient variability. According to the interactions among the studied factors, the studied genotypes responded differently to the water treatments and seasons, allowing to select the favorable genotypes. In this respect, the evaluation of wheat genotypes under wellwatered compared to water-deficit conditions was proved to be useful to detect tolerant genotypes to water deficit (Morsy et al., 2021). In addition, the breeders could select the adaptive genotypes to water deficit using morphological and physiological indices (Shalaby et al. 2020). In this respect, Shehab-Eldeen and Farhat (2020) found significant genetic variability among the studied genotypes under the two studied seasons and the two water treatments.

The highest values in the second season may be a result of the lowest temperature and higher relative humidity than in the first one. Similar results were obtained by Farhat et al. (2020) and Shehab-Eldeen and Farhat (2020).

Averaging across the studied genotypes, the water deficit reduced all studied characters, except for proline content and leaf temperature. These results were confirmed by Shalaby et al. (2020), ShehabEldeen and Farhat (2020), Morsy et al. (2021), Mu et al. (2021) and Wasaya et al. (2021). 


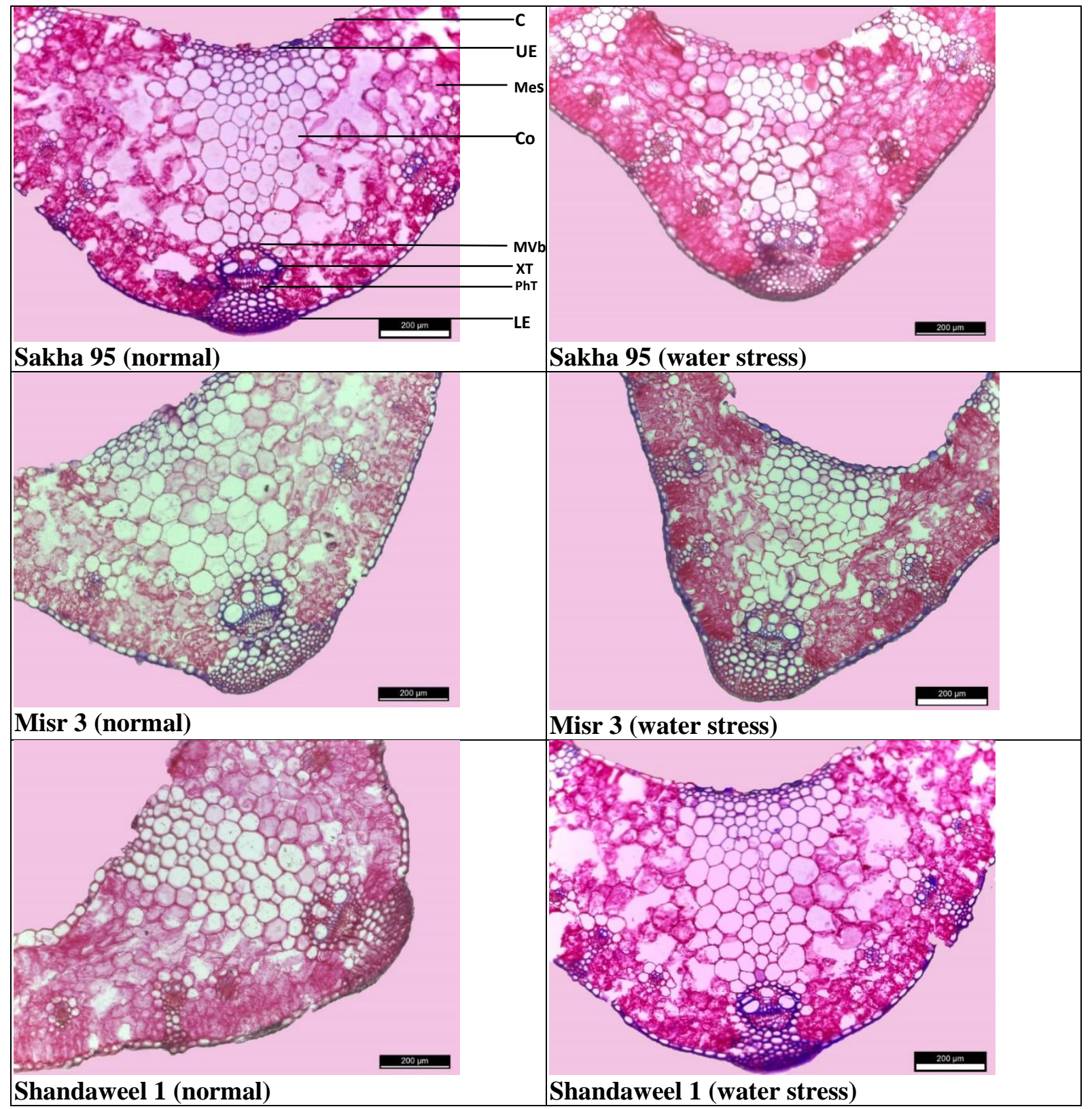

Figure 1. Transverse sections in the leaf of the wheat cultivars Sakha 95, Misr 3 and Shandaweel 1 under two irrigation levels. C: cuticle, UE: upper epidermis, LE: lower epidermis, MVb: main vascular bundle, XT: xylem Tissue, PhT: phloem tissue and Col: collenchyma tissue.

The grain number was reduced under water deficit and similar results were obtained by Senapati et al. (2019).The reduction in grain number may be due to premature abortion of florets (Dolferus et al., 2013) and male and female sterility (Onyemaobi et al., 2017). Additionally, the reduction of grain weight under the water deficit was observed by Zhao et al. (2020), who explained that for the shorter grain-filling times under water stress and then lower dry matter accumulation or a reduced rate and duration of starch accumulation in the endosperm.

In earlier studies, grain yield was reported to be decreased under water stress due to the decrease in grain weight per spike (Zhao et al., 2020), grain number per spike (Ehdaie et al., 2008) and spike number per square meter (Leilah and Al-Khateeb, 2005). The reduction $\%$ as a result of water stress was also detected by previous studies and reached $9.54 \%$ 


\section{Farhat WZE et al., 2021}

(Al-Naggar et al., 2020), 77.29, 76.44 and 76.78\% (Shalaby et al., 2020) and 46.8\% (Nehe et al., 2021).

Relative water content reveals plant water status and is considered an index of dehydration stress tolerance (Dehnavi et al., 2017 and Marček et al., 2019). In addition, Relative water content reveals is considered to be a good index to detect the water stress-tolerant genotypes (Din et al., 2020). The reduction in leaf relative water content ultimately leads to reducing growth and biomass production (Wasaya et al., 2021). Moreover, water deficit-tolerant genotypes maintained more water contents under limited water treatment (Allahverdiyev 2015andWasaya et al., 2021).

Belay et al. (2021) reported that proline content increased under water stress compared to normal irrigation. Where plants cope water stress by assembling high amounts of inorganic ions or producing low molecular weight organic solutes like proline for osmotic adjustments (Ben Rejeb et al., 2014). Proline and other osmotic adjustments increasing save the plants from dehydration under water stress conditions. Also, proline as an enzymatic antioxidant protects membranes from oxidative stress by ROS under water deficit.

The chlorophyll content parallels the photosynthesis and could be used to assess stress tolerance of genotypes (Shabala and Munns, 2017). The reduction in chlorophyll contents under water stress conditions may be mainly due to chloroplasts damage caused by the reactive oxygen species (ROS) which formed under water deficit stress conditions (Shalaby et al., 2020and Khayatnezhad and Gholamin, 2021). Reduced chlorophyll causes chlorosis and leads to a reduction in photosynthesis (Yang et al., 2001).

The lowest leaf temperature could be used as an indicator of plant water status and a possible mechanism of stress avoidance. The lowering leaf temperatures could be due to an increased root suction power, allowing plants to absorb water and transpire it, thereby cooling their leaves (El-Gammaal, 2018, Doneva et al., 2021 and Takashima et al., 2021). Similar results were reported by Zada et al. (2020) who stated that drought stress condition considerably reduced the leaf potential and relative water content and transpiration rate with an associated raised in leaf temperature. In general, leaf temperatures were cooler than air temperatures under well-watered conditions, while leaves were warmer than air temperatures under water-stressed conditions (Perera et al., 2019).

Based on the water stress susceptibility Line 1, Line 2, Sids 14, Giza 171 and Sakha 95 were the most tolerant ones under water deficit. In addition, these genotypes showed preferable values of grain yield, relative water content, proline, chlorophyll contents and cooler leaf temperatures. In this respect, El-Nagar (2019), concluded that Shandaweel 1 was the most drought-sensitive genotype compared to the other studied cultivars in their study.

Drought stress reduces crop yield because of some anatomical changes. In this study the means of the three cultivars (Sakha 95, Misr 3 and Shandaweel 1) decreased for all leaf anatomical characters under water stress. These results are in harmony with Ghanem (2008), Farhat (2009), Jafarian et al. (2012), and Hassan et al. (2017). They reported that water stress decreased most of the leaf anatomical characters.

The anatomical modification in leaf architecture of the plant plays an important role in resisting drought stress (Balsamo et al., 2006), where Sakha 95 (the most tolerant variety) showed compact mesophyll cells, sunken \& closed stomata, thick cuticle layer and small vascular bundle under water deficiency. Cuticle plays a vital role in regulating water loss (Bi et al. 2017). And Mesophyll tissue appeared compacted because of absence of intercellular spaces, where this criterion is considered to be highly indicative of the resistance to water flow (David et al., 2017). Moreover, the smallest vascular bundles are more efficient in water and nutrient conduction, Hameed et al. (2012). These results indicate that tolerant genotypes modify their leaf characters to adapt to drought stress similar observations of anatomical characters under drought stress have been reported (Jäger et al., 2014, David et al., 2017, and Hassan et al., 2017). Therefore, changing the anatomical characteristics of leaves under stress is considered an indicator of the regulation of photosynthesis at the morphological level (Adhikary et al., 2007). The reduction in mesophyll, xylem, and phloem tissues slows the rate of the translocation of photo-assimilatess and the accumulation of necessary water for photosynthesis (Hassan et al., 2017).

\section{CONCLUSION}

This study concluded that Line 1, Line 2, Sids 14, Giza 171 and Sakha 95 were suitable cultivars to be cultivated under water shortage conditions. High values of relative water content, chlorophyll-and proline contents, low values of leaf temperature, in addition to lowest reduction in leaf anatomical characters may be a useful selection criterion for water stress tolerance in wheat genotypes. 


\section{ACKNOWLEDGEMENTS}

This research was supported by Wheat Research Department, Field Crops research, ARC, Egypt.

\section{REFERENCES}

Adhikary SK, Alam MZ, Haider SA, Paul NK (2007). Leaf anatomical characters in relation to grain yield of wheat (Triticum aestivum L.) cultivars. J. Biosci., 15: 153-158.

Allahverdiyev TI (2015). Physiological traits of durum wheat (Triticum durum Desf.) and bread wheat (Triticum aestivum L.) genotypes under drought stress. Agricultural Sciences, 6(08): 848.

Al-Naggar AMM, AbdEl-Shafi MA, El-Shal MH, Anany AH (2020). Evaluation of Egyptian wheat landraces (Triticum aestivum 1.) for drought tolerance, agronomic, grain yield and quality traits. Plant Archives Vol. Supplement 20, 3487-3504

Balsamo RA, Willigen CV, Bauer AM, Farrant J (2006). Drought tolerance of selected Eragrostis species correlates with leaf tensile properties. Ann Bot 97:985-991

Bates LS, Walden RP, Teare ID (1973). Rapid determination of free proline for water studies. Plant and Soil., 39: 205-208.

Belay GA, Zhang Z, Xu P (2021). PhysioMorphological and Biochemical Trait-Based Evaluation of Ethiopian and Chinese Wheat Germplasm for Drought Tolerance at the Seedling Stage. Sustainability, 13(9): 4605.

Ben Rejeb K, Abdelly C, Savoure A (2014). How reactive oxygen species and proline face stress together. Plant Physiol Biochem 80: 278-284.

Bi H, Kovalchuk N, Langridge P, Tricker PJ, Lopato S, Borisjuk N (2017). The impact of drought on wheat leaf cuticle properties. BMC Plant Biology, 17(1), 1-13.

David OA, Osonubi O, Olaiya CO, Agbolade JO, Ajiboye AA, Komolafe RJ, Chukwuma DM, Akomolafe GF (2017). Anatomical response of wheat cultivars to drought stress. Ife Journal of Science, 19(2). 323-331.

Dehnavi MM, Zarei T, Khajeeyan R, Merajipoor $M$ (2017). drought and salinity impacts on bread wheat in a hydroponic culture: a physiological comparison. journal of plant physiology and breeding. 7(1): 61-74.

Din A, Ahmad M, Watto FM, Ahmed S, Ali I, Shah MKN(2020). Drought tolerance screening in thirty common wheat (Triticum aestivum L.) genotypes. Sarhad Journal of Agriculture 35 (1): 168-177.

Dolferus R, Powell N, JI X, Ravash R, Edlington J, Oliver S, Dongen JV, Shiran B (2013). The physiology of reproductive-stage abiotic stress tolerance in cereals. In: Rout G. R. and A. B. Das eds. Molecular stress physiology of plants. New Delhi, India, Springer: 193-216.

Doneva D, Pal M, Brankova L, Szalai G, Tajti J, Khalil R, Ivanovska B, Velikova V, Misheva S, Janda T, Peeva V (2021). The effects of putrescine pre-treatment on osmotic stress responses in droughttolerant and drought-sensitive wheat seedlings. Physiol Plant 171(2): 200-216.

Ehdaie B, Alloush GA, Waines JG (2008). Genotypic variation in linear rate of grain growth and contribution of stem reserves to grain yield in wheat. Field Crops Res. 106: 34-43.

El Gataa Z, El Hanafi S, Basheer F, Kehel Z, bouhouch Y, El Messoadi K, Eddakir K, Ladraa N, Samir K, Tadesse W (2021). Genome wide association study of grain yield and yield related traits in spring bread wheat (Triticum aestivum 1.) under drought and heat conditions in three different locations. Journal of Crop Science and Biotechnology: $1-13$.

El-Gammaal A (2018). Combining ability analysis of drought tolerance screening techniques among wheat genotypes (Triticum aestivum, L). Journal of Plant Production 9: 875-885.

El-Nagar MIM (2019). Comparative morphophysiological responses of Egyptian wheat cultivars to water stress, Mansoura University. M. Sc.

Evans JR, Caemmerer SV, Setchell BA, Hudson GS (1994). The relationship between $\mathrm{CO}_{2}$ transfer conductance and leaf anatomy in transgenic tobacco with a reduced content of rubisco. Aust. J. Plant Physiol., 21(4):475-495.

Fang Y, Xiong L (2015). General mechanisms of drought response and their application in drought resistance improvement in plants. Cell Mol. Life Sci., 72(4): 673-689.

Farhat WZE (2009). Genetic, physiological and anatomical response of some wheat crosses to water stress. Ph. D. Thesis, Fac. Agric., Kafrelsheikh Univ., Egypt.

Farhat WZE, Shehab-Eldeen MT, Khedr RA (2020). Agronomic and physiological studies on some exotic and local bread wheat genotypes under saline soil conditions in north delta region. Egypt. J. Plant Breed. 24(2): 465-491.

Fischer RA, Maurer R (1978). Drought resistance in spring wheat cultivars I. Grain yield responses. Aust. J. Agric. Res., 29:897-912.

Ghanem Rania HA (2008). Breeding of some bread wheat varieties (Triticum aestivum L.) under water stress conditions. Ph. D. Thesis, Fac. Agric., Cairo 
Univ., Egypt.

Gonzalez L, Gonzalez-Vilar M (2001). "Determination of relative water content". In: Reigosa, M. J. (Ed.), Handbook of Plant Ecophysiology Techniques. Kluwer Academic Publishers, Dordrecht (2001): 207-212.

Hameed M, Batool S, Naz N, Nawaz T, Ashraf M (2012). Leaf structural modifications for drought tolerance in some differentially adapted ecotypes of blue panic (Panicum antidotale Retz.). Acta physiologiae plantarum, 34(4), 1479-1491.

Hassan Manal A, Sheren Nathan N, Eid T, Eisa G (2017). Performance of grain yield, biochemical and anatomical characters under water stress conditions in some bread wheat genotypes. Zagazig Jo. Agric. Res., 44(1): 171-190.

Jafarian T, Moud AM, Saffari VR (2012). Water stress effects on winter and spring leaves anatomy of different wheat (Triticum aestivum L.) genotypes. Journal of Plant Physiology Breeding science, 2 (2): 23-34.

Jäger K, Fábián A, Eitel G, Szabó L, Deáak C, Barnabáas B, Papp I (2014). A morphophysiological approach differentiates bread wheat cultivars of contrasting tolerance under cyclic water stress. Journal of Plant Physiology, 171: 1256-1266.

Khayatnezhad M, Gholamin R (2021). The effect of drought stress on the superoxide dismutase and chlorophyll content in durum wheat genotypes. Adv. Life Sci., 8: 119-123.

Leilah AA, Al-Khateeb SA (2005). Statistical analysis of wheat yield under drought conditions. J. Arid Environ., 61: 483-496.

Levene $H$ (1960). Levene test for equality of variances. Contributions to probability and statistics, 278-292.

Marček T, Hamow KA, Vegh B, Janda T, Darko E (2019). Metabolic response to drought in six winter wheat genotypes. PLoS ONE 2019, 14, e0212411.

Microsoft EXCEL (2016). Computer user's guide.

Moran R (1982). Formulae for determination of chlorophyll pigments with $\mathrm{N}, \mathrm{N}$-Dimethylformamid. Plant Physiol., 69 (6): 1376-1381.

Morsy SM, Elbasyoni IS, Abdallah AM, Baenziger PS (2021). Imposing water deficit on modern and wild wheat collections to identify drought-resilient genotypes. Journal of Agronomy and Crop Science 00: 1-14.

Mu Q, Cai H, Sun S, Wen S, Xu J, Dong M, Saddique Q (2021). The physiological response of winter wheat under short-term drought conditions and the sensitivity of different indices to soil water changes. Agricultural Water Management 243:
106475.

Mujeeb-Kazi A, Munns R, Rasheed A, Ogbonnaya FC, Ali N, Hollington P, Dundas I, Saeed N, Wang R, Rengasamy P, Saddiq MS, De León JLD, Ashraf M, Rajaram S (2019). Breeding strategies for structuring salinity tolerance in wheat. Advances in Agronomy. Vol. 155. Academic Press, 121-187.

Mwadzingeni L, Shimelis H, Dube E, Laing MD, Tsilo TJ (2016). Breeding wheat for drought tolerance: Progress and technologies. J. Integr. Agric. 15: 935-943.

Nehe AS, Foulkes MJ, Ozturk I, Rasheed A, York L, Kefauver SC, Ozdemir F, Morgounov A (2021). Root and canopy traits and adaptability genes explain drought tolerance responses in winter wheat. PLoS One 16 (4): e0242472.

Niinemets U, Sack L (2006). Structural determinants of leaf light harvesting capacity and photosynthetic potentials. In: Esser et al. (Eds). Progress in Botany, Vol. 67. Springer-VerlagBerlin, pp. 385-419.

Onyemaobi I, Liu H, Siddique KH, Yan G (2017). Both male and female malfunction contributes to yield reduction under water stress during meiosis in bread wheat. Frontiers in Plant Science, 7: 2071.

Payne RW, Murray DA, Harding SA (2017). An introduction to the GenStat command language. Hemel Hempstead, UK: VSN International.

Perera RS, Cullen BR, Eckard RJ (2019). Using leaf temperature to improve simulation of heat and drought stresses in a biophysical model. Plants (Basel) 9(8): doi:10.3390/plants9010008.

Rojas L, Recio O, Decastro ME (1983). Leaf xeromorphism and drought resistance in two sugarcane varieties. Ciencias de la Agriculture, 16: 337.

Senapati N, Stratonovitch P, Paul MJ, Semenov MA (2019). Drought tolerance during reproductive development is important for increasing wheat yield potential under climate change in Europe. J. Exp. Bot. 70: 2549-2560.

Shabala S, Munns R (2017). Salinity stress: physiological constraints and adaptive mechanisms. In Shabala, S. (Ed.), Plant stress physiology $\left(2^{\text {nd }} E d .\right.$, pp. 24-63). Croydon, UK.: CAB International.

Shalaby E, Galall E, Ali M, Amro A, El Ramly A (2020). Growth and yield responses of ten wheat (Triticum aestivum L) genotypes to drought. SVUInternational Journal of Agricultural Sciences 2: 1-17.

Shehab-Eldeen MT, Farhat WZE (2020). Response of some exotic bread wheat genotypes to reduced irrigation in north Delta region of Egypt. Egypt. J. Plant Breed., 24 (4): 793-815.

Steel RGD, Torrie JH, Dicky DA (1997). Principles 


\section{Scientific Journal of Agricultural Sciences 3 (2): 145-160, 2021}

and procedures of statistics, A biometrical approach. $3^{\text {rd }}$ Edition, McGraw Hill, Inc. Book Co., New York, 352-358.

Takashima Y, Hiraoka Y, Matsushita M, Takahashi M (2021). Evaluation of responsivity to drought stress using infrared thermography and chlorophyll fluorescence in potted clones of Cryptomeria japonica. Forests 12(1): 55.

Wasaya A, Manzoor S, Yasir TA, Sarwar N, Mubeen K, Ismail IA, Raza A, Rehman A, Hossain A, El Sabagh A (2021). Evaluation of fourteen bread wheat (Triticum aestivum L.) genotypes by observing gas exchange parameters, relative water and chlorophyll content, and yield attributes under drought stress. Sustainability 13: 1-15.
Willey RL (1971). Microtechniques: A Laboratory Guie. Macmillan Publishing Co., Inc., New York. 99 p.

Yang J, Zhang J, Wang Z, Zhu Q, Liu L (2001). Water deficit induced senescence and its relationship to the remobilization of pre-stored carbon in wheat during grain filling. Agron. J., 93: 196-206.

Zada A, Ali A, Shah A, Gill S, Hussain I, Ullah Z, Sher $H$ (2020). Physiological and molecular characterization of bread wheat (Triticum aestivum L.) for drought resistance. Authorea September 17.

Zhao W, Liu L, Shen Q, Yang J, Han X, Tian F, Wu J (2020). Effects of water stress on photosynthesis, yield, and water use efficiency in winter wheat. Water 12(8): 2127.

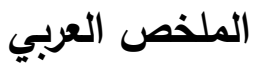

\section{استجابة بعض الصفات الزراعية والففيولوجية والتشريحية في بعض تراكيب قمح الخبز تعت الري المتناقص في منطقة شمال الالتا}

$$
\begin{aligned}
& \text { وليد ذكي اليماني فرحات'، رانيا أنور خضر ' وشيماء عبدالسلام شعبان" } \\
& \text { ' قسم بحوث القمح، معهذ بحوث المحاصيل الحقلية، مركز البحوث الزراعية، مصر ، }
\end{aligned}
$$

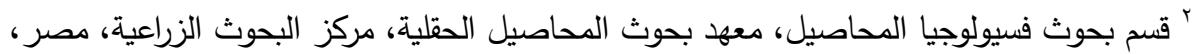

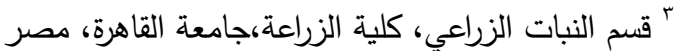

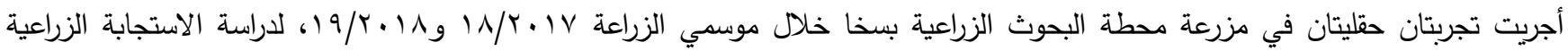
والفسيولوجية والتشريحية لأحد عشر صنفا وسلالة من قمح الخبز تحت معاملتين من الري (خمس ريات (موصى به كمعاملة مقارنة) ورية واحدة

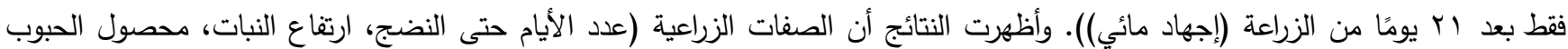

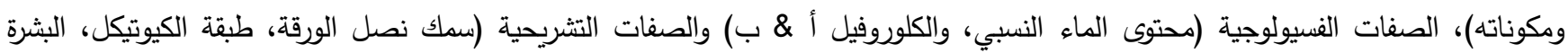
العليا، البشرة السفلى، نسيج الميزوفيل، العرق الوسطي، النسيج الكولنشيهي، نسيجا الخشب واللحاء، وطول وعرض الحزمة الوعائية الرئيسية وسمك

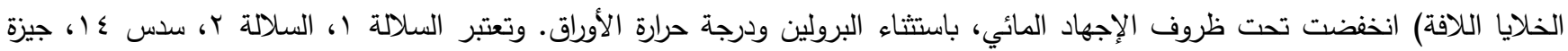

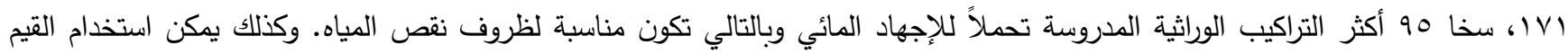

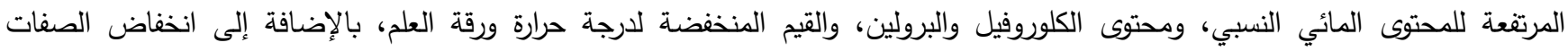

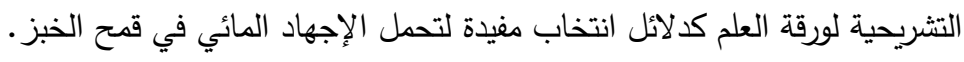

